
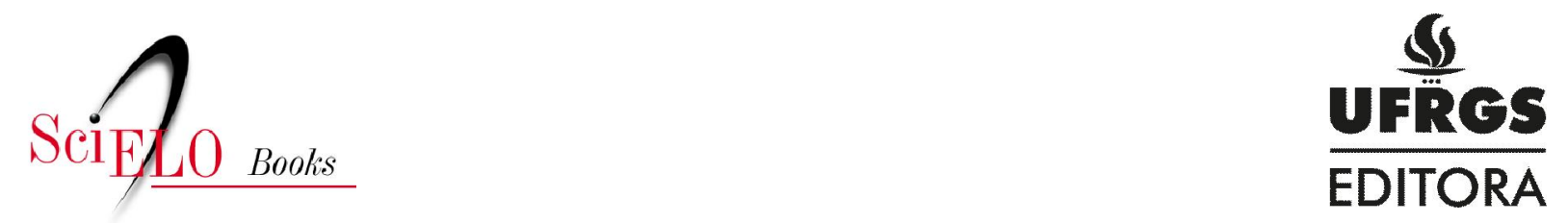

\title{
Definições e indefinições do livro de artista
}

\author{
Paulo Silveira
}

SciELO Books / SciELO Livros / SciELO Libros

SILVEIRA, P. Definições e indefinições do livro de artista. In: A página violada: da ternura à injúria na construção do livro de artista [online]. 2nd ed. Porto Alegre: Editora da UFRGS, 2008, pp. 25-71. ISBN 978-85-386-0390-0. Available from doi: 10.7476/9788538603900. Also available in ePUB from: http://books.scielo.org/id/2pwn4/epub/silveira-9788538603900.epub.

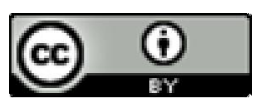

All the contents of this work, except where otherwise noted, is licensed under a Creative Commons Attribution 4.0 International license.

Todo o conteúdo deste trabalho, exceto quando houver ressalva, é publicado sob a licença Creative Commons Atribição 4.0.

Todo el contenido de esta obra, excepto donde se indique lo contrario, está bajo licencia de la licencia $\underline{\text { Creative Commons }}$ $\underline{\text { Reconocimento } 4.0 .}$. 


\section{Definições e indefinições do livro de artista}

\section{Grafia e significado de livro de artista}

Como em outros idiomas, o português contemplou com muitas palavras o campo em que o artista se envolve na construção do livro como obra de arte: livro de artista, livro-objeto, livro ilustrado, livro de arte, livro-poema, poema-livro, livro-arte, arte-livro, livro-obra... A designação "arte do livro" (que será discutida em outro capítulo) não nos serve porque nosso relativo provincianismo a relegou ao mundo técnico, quer artesanal, quer industrial. Utilizo, por isso e por outros motivos que veremos, "livro de artista" para designar um grande campo artístico (ou categoria) no sentido lato, que também poderia ser chamado de livro-arte ou outro nome. Mas como a realidade dos eventos determina esse uso, assim o farei. Também é usado "livro de artista" no sentido estrito, referente ao produto específico gerado a partir das experiências conceituais dos anos 60 .

A unidade locucional livro de artista não foi encontrada em dicionários brasileiros. Das obras de referência, apenas uma registra o termo, a Grande Enciclopédia Larousse Cultural, desde a sua edição de 1988 até a última consultada, de 1998, sem alterações. É assim definido: "Livro de artista, obra em forma de livro, inteiramente concebida pelo artista e que não se limita a um trabalho de ilustração. (Sob sua forma mais livre, o livro de artista torna-se livro-objeto.)". Livro-objeto é o "objeto tipográfico e/ou plástico formado por elementos de natureza e arranjos variados". A enciclopédia não exemplifica o livro de artista, mas o livro-objeto é exemplificado (apenas nominalmente) por $L a$ prose du Transsibérien, 1913, "de Cendrars, por S. Delaunay" (esse "de" e esse "por" serão assunto para comentários posteriores). Esse conceito tem uma notável concisão. Mas o presente trabalho deverá demonstrar, às vezes incidentalmente, que: (1) livro de artista pode mesmo designar tanto a obra como a categoria artística; (2) o conceito é ainda muito problemático, pondo em xeque pesquisadores com pesquisadores, artistas com artistas, e pesquisadores com artistas, além de envolver outras especialidades, como 
estética, literatura, biblioteconomia e comunicação; (3) que a concepção e execução pode ser apenas parcialmente executada pelo artista, com colaboração interdisciplinar; (4) que não precisa ser um livro, bastando ser a ele referente, mesmo que remotamente; e (5) que os limites envolvem questões do afeto expressadas através das propostas gráficas, plásticas ou de leitura.

Um fato curioso acabou por se transformar em problema cada vez maior. Livro de artista é encontrado em ensaios ora grafado com, ora sem hífen. Foram usados hifens - "livro-de-artista" - em projetos editoriais sofisticados, como em Zanini, 1983, ou no catálogo geral (incluindo o seu regulamento) da XVI Bienal de São Paulo, 1981. Às vezes um mesmo catálogo apresenta as duas grafias (talvez por exigência dos autores), como em Brasil: sinais de arte, 1993. Como a colocação dos hifens poderia ser resultante de um entendimento conceitual ou não, foi feita uma consulta ao Instituto Antônio Houaiss de Lexicografia e Banco de Dados da Língua Portuguesa. Segundo Mauro de Salles Villar, diretor, o sintagma "livro de artista" deve ser grafado sem hifens, não havendo motivos para dúvidas.

A hifenação de sintagmas deve ser feita quando a eles corresponde uma informação nova, não dedutível ou praticamente não dedutível da soma dos sentidos dos vocábulos empregados em sua composição. Por exemplo: quem conheça o significado das palavras anjo e papo não infere o sentido do sintagma papo-de-anjo. Esta é a razão de sua hifenação.

Ocorre, porém, que os usos ortográficos da língua nem sempre seguem esse modelo lógico. Quem souber o que significa o adjetivo morto e o substantivo ponto não chegará a deduzir o que é ponto morto. O mesmo com menina dos olhos. Trata-se de sintagmas tão lexicalizados como o primeiro; só que estes se grafam oficialmente sem hífen.

O sentido da locução livro de artista infere-se a partir de suas partes formantes, não importa se a expressão possa, por extensão ou metaforicamente, significar coisas mais distantes do que a acepção inicial de um objeto (o livro) feito, concebido, realizado, criado por um artista no uso de toda a sua liberdade de relacionar ideias e materiais, objetivos e intenções etc. Já por isto não seria um bom candidato à hifenização. Mas há mais: relutamos em hifenizar palavras que não estejam assim registradas nos vocabulários ortográficos da língua, para não aumentar o tumulto que representa o problema do hífen em português, e, como o senhor poderá constatar, não há livro-de-artista no Vocabulário Ortográfico da Língua Portuguesa, da Academia Brasileira de Letras (1981, Rio), um inventário de mais de 360 mil vocábulos usados no português.

O melhor será, então, que esse sintagma se una a inúmeros outros iniciados pela palavra livuro não hifenizados, sobre os quais jamais pairou dúvida sobre a conveniência de hifenização.

A resposta foi recebida por carta do Rio de Janeiro, de 24 de fevereiro de 1999 (Silveira, 1999, "Anexos"). Para a consulta a Villar foram enviadas fotocópias de diversos artigos demonstrando a ocorrência das duas grafias. Por mais que pareça pouco, a presença ou não dos hifens pode-se tornar um pequeno tormento, principalmente quando um teórico o usa para realçar a singularidade de um conceito. 


\section{Por que ternura e injúria}

Pretendo que essas palavras sejam guias e não camisas-de-força desta pesquisa.Talvez fosse preferível eu quase não as usar mais adiante. Mas elas são importantes porque representam uma emoção pressentida por impulso, ainda antes da racionalização. Elas dão o colorido que caracteriza o envolvimento dos afetos na percepção ou leitura da obra de arte, considerada a carga de imposturas que essa relação engendra.

Deve-se ter algumas preocupações na busca dos significados e de suas associações para as palavras ternura e injúria. O esperado, em se falando de Brasil, é o uso do Novo dicionário da língua portuguesa, de Aurélio Buarque de Holanda Ferreira. É um livro um pouco seco e, às vezes, inadequado, embora granjeie admiração do público, a ponto de "aurélio", em português do Brasil, ser, hoje, sinônimo de dicionário. Penso que ele pode ser dispensado em favor daqueles que exponham com mais sensibilidade seus conceitos, em cruzamento com outros que tratem do português de Portugal. Mas como alguns leitores não aceitariam outras informações sem antes saber o que está no Aurélio, não há por que omitir o seu registro. Ternura é a "1. Qualidade de terno [brando, suave] [...]. 2. Meiguice, carinho. 3. Afeto brando ou sem grandes transportes". Injúria é "1. Ato ou efeito de injuriar. 2. Aquilo que é injusto. 3. Ato ou dito ofensivo a alguém; agravo, insulto. 4.Jur. Ofensa à dignidade ou decoro de alguém. 5. Med. Traumatismo produzido, em geral por força externa". Injuriar, por sua vez, é "ofender por ação ou dito infamante; [...] desonrar, [...] causar dano ou estrago" (conforme a segunda edição; Rio de Janeiro: Editora Nova Fronteira, 1986). As acepções dos termos são mesmo claras e abrangentes. Mas vou acrescentar à consulta algumas obras anteriores ao sucesso editorial do dicionário Aurélio, que considero mais significativas para esse estudo.

No Grande e novíssimo dicionário da lingua portuguesa, de Laudelino Freire (Rio de Janeiro: José Olympio, 1957, segunda edição, cinco volumes), essas significações já estavam registradas. Acrescente-se, entretanto, a terceira acepção para injúria, "violação do direito de outrem", e a acepção extra, "injúria física", como traumatismo. Quanto a ternura, o verbete é exatamente igual, talvez porque esse parece ter sido o dicionário básico para o dicionário Aurélio. A obra de Laudelino Freire foi o primeiro grande dicionário com o português do Brasil e de Portugal, simultaneamente, substituindo em importância o trabalho de Antônio de Morais e Silva, elaborado, em sua edição original, há mais de um século, em Portugal e Londres.

Para Artur Bivar, autor do Dicionário geral e analógico da língua portuguesa (Porto: Edições Ouro, 1952), ternura é a "qualidade do que é terno; meiguice; afeto suave e carinhoso". Antônio de Morais e Silva, no seu Grande dicionário da lingua portuguesa (Lisboa: Editorial Confluência, edição de 1957), acrescentaria “[...] afeto brando e sem grandes transportes [...]". Ternura vem de terno, do latim tenerum, adjetivo que significa "meigo, afetuoso", segundo o Dicionário etimológico Nova Fronteira da lingua portuguesa, 
de Antônio Geraldo da Cunha. O radical é o mesmo de enternecer ou terneiro.

Quanto à injúria, Artur Bivar é conciso. Injúria é "ofensa, agravo, insulto. Aquilo que é contra o direito. Detrimento. Dano, estrago". Antenor Nascentes, no Dicionário da lingua portuguesa (da Academia Brasileira de Letras; Rio de Janeiro: Departamento de Imprensa Nacional, 1964), descreve injúria num amplo verbete: "Julgamento injusto relativo à dignidade ou à honra de uma pessoa. Ofensa à dignidade ou ao decoro de alguém. Ato ou dito com que se ofende a alguém. Agravo, insulto. Violação do direito alheio, injustiça. Dano, detrimento, estrago, efeito prejudicial: A injúria do tempo.” Antônio de Morais e Silva, na obra já citada, acrescenta: “[...] As intempéries do ar ou das estações, como o vento, a chuva, a neve, o nevoeiro, consideradas em relação aos incômodos ou prejuízos que causam; dano, estrago, detrimento [...]”. O Dicionário etimológico Nova Fronteira se refere apenas ao perfil moral do termo: "injustiça, insulto, ofensa à dignidade ou ao decoro de alguém”. Do latim injuria.

Tanto no sentido próprio, como no sentido figurado, não são registradas modificações importantes de significado entre o latim e o português contemporâneo para as duas palavras. Ternura e injúria são gestos. São a expressão de sentimentos de proteção ou de agravo a algo.

No presente trabalho, ternura é o gesto de preservação às conformações tradicionais, assim como aos valores institucionais do livro. É amor à forma livro, manifestada pelo zelo a essa forma, pela manutenção de sua tradição (de sua forma instituída), pela defesa de sua permanência perante as novas mídias ou pela preservação da leitura sequencial da palavra escrita. É carinho pela crença na verdade impressa. É o aceite e a dependência do fetiche.

Injúria é agravo ao livro. É a tentativa de sua negação. É o comentário ao suporte pela sua subversão e afronta. É o comprometimento da verdade e/ou da verossimilhança, ou o uso dessa em detrimento daquela. Injúria implica perversão. É dano físico porque presume e tenta violar a permanência temporal do livro. É dano moral porque presume e tenta violar seu legado de lei e verdade. É o esforço de ataque ao fetiche.

O sentimento do livro como objeto sagrado é fonte de nossas mais banais manifestações de ternura em relação a ele. Quem vive entre o livro e a arte já deve estar can- 
sado de ouvir a proposição de Stéphane Mallarmé de que "tudo no mundo existe a fim de terminar como um livro". É uma afirmação lírica e sedutora, muito repetida, tirada de seu pequeno texto Le livre, instrument spirituel. Fora do contexto, ela passa a servir como motivo para a nossa devoção. Mas o título do artigo demonstra a convivência do físico, pelo "instrumento", com o afetivo, pelo "espiritual". Mais adiante esse paralelismo será sugerido pela menção ao livro não aparado como sendo um corpo virgem a ser possuído, "pronto para um sacrifício pelo qual as bordas vermelhas dos livros antigos sangram; a introdução de uma arma, ou espátula, para estabelecer a tomada de posse". Prossegue acusando esse como um processo cego, "um assalto que é cometido através da destruição de uma inviolabilidade frágil" (Mallarmé, 1996, p.14-20). Ter o livro, sim, lê-lo também, mas também, e sobretudo, ver, virar e gerar as suas páginas. Comê-las. É preciso construí-lo como objeto de arte. Libertar-se não

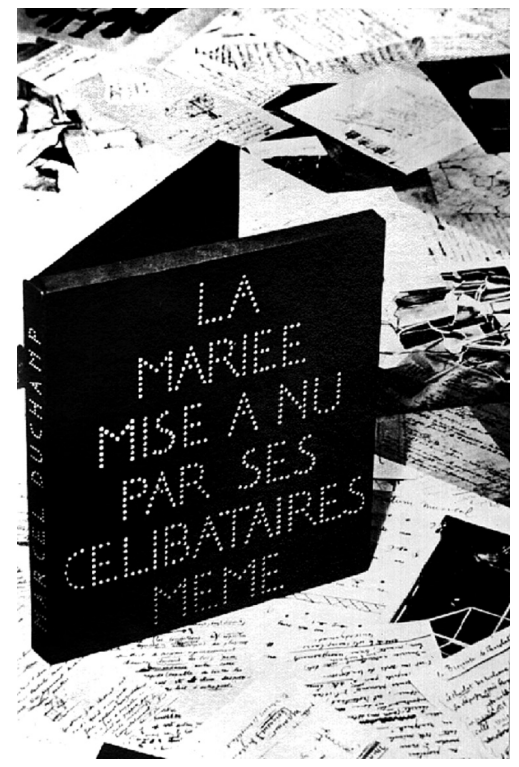

Marcel Duchamp, Caixa verde, 1934

(foto fornecida avulsa, de fonte ignorada). apenas do verso, mas da própria regra da página, sim ou não? À arte cabe essa liberdade, mesmo se melancólica. Como no Readymade infeliz, 1919, de Marcel Duchamp (ele de novo!), em que um manual de geometria deveria ser exposto ao tempo na varanda da casa de sua irmã. $O$ vento viraria as páginas e escolheria os problemas matemáticos a serem destruídos pela intempérie.

$\mathrm{O}$ apego ao belo tem exércitos de representantes na arte. Mas a relatividade do gesto terno e a participação criadora das diversas possibilidades de rupturas pela ação ou pela emoção estão indicadas desde as considerações sutis sobre o papel dos opostos por Paul Klee, ou no questionamento sobre a negligência excessiva do elemento destrutivo na criação por Piet Mondrian, até os fatos explícitos de Lucio Fontana, Jean Tinguely e todos os experimentadores contemporâneos dos aspectos destrutivos, degenerativos e matéricos em arte. ${ }^{1}$ Parece natural que o livro, um suporte preexistente e com regras, significados e tradições enseje atitudes artísticas antagônicas expressas em sua elaboração.

A ternura não pressupõe confrontos. A ideia de algo que se oponha a outra coisa é da instância do conflito, sendo a injúria não mais que a ação física ou imaterial gerada por ambas ou uma das unidades em oposição. Nesse sentido, talvez a injúria pudesse

\footnotetext{
${ }^{1}$ As reflexões feitas por esses e outros artistas podem ser encontradas em seus próprios escritos ou em manifestos de seus movimentos. Para uma consulta mais rápida e ágil, ver as antologias de Chipp, 1988, e de Stiles e Selz, 1996.
} 
ser tanto deformativa quanto conformativa, em espírito ou na matéria. A injúria é fruto do versus. A ternura é a negação do versus, ou, como perversão, amor ao versus.

As definições de ternura e injúria implicam, cada uma delas, áreas de entendimento limitadas por linhas que podemos considerar como móveis. E, além disso, essas linhas se contorcem sobre suportes (as variações físicas do livro) que, de aparência fixa, são realmente tão movediços quanto o possibilitado pela criação artística. Ternura e injúria estão em maior ou menor grau presentes na categoria do livro de artista, principalmente na manifestação de sua poiese, embora possam parecer mais evidentes em sua poética. O equilíbrio ou desequilíbrio de sua presença gera a desejada tensão plástica da página, ou do volume. São elementos fundantes, definidores da estrutura dessa forma especial de arte que devem ser recenseados e considerados na sua análise crítica.

Em que medida a ternura é construção? E será que toda injúria é desconstrução? Acho que às vezes esses papéis se invertem: o que é par fica ímpar.

Tendo, então, mais claro o que esse trabalho define como ternura e injúria, podemos passar para a compreensão dos conceitos relacionados ao livro de artista, por si sós ainda problemáticos em alguns círculos intelectuais.

\section{Introdução ao problema do conceito "livro de artista"}

Nem tudo neste estudo é problema plástico. O seu próprio conceito (a sua definição) tem também demonstrado construir um problema. Talvez devesse ser o primeiro, mas ele surgiu depois, cronologicamente, a partir do levantamento das fontes bibliográficas disponíveis, primárias ou secundárias. O conceito está fortemente relacionado com a delimitação no tempo histórico, seu primeiro balizador. As evidências demonstram que podemos retroceder no tempo quase indefinidamente na busca da origem do livro de artista. É um fato: a Caixa verde, de Marcel Duchamp (1934), é um claro livro de artista (ou, mais especificamente, livro-objeto). Assim como também o são os livros de William Blake, publicados entre 1788 e 1821, ou qualquer dos cadernos de Leonardo da Vinci, executados no século 15 e começo do 16, sem possibilidade de publicação. Retroaplicar conceitos nos permite ir até onde quisermos. Porém é no final do século 20 que o entendimento da autonomia desse tipo de obra de arte é legitimado. Principalmente a partir dos anos 60, pela mutação causada pela companhia do conceitualismo, com a sua maior divulgação nos anos 70, época de grande incremento dos canais internacionais de informação e da consoante multiplicação de considerações teóricas. Mas embora já afirmado na década dos 80, ainda nos 90 existem pequenos desentendimentos conceituais em face da persistência das novas soluções matéricas.

Os anos 80 foram especialmente frutíferos ao livro-objeto, com o reingresso dos ensinamentos das técnicas históricas de encadernação, subvertidos para colaborar com a constituição de uma linguagem, aliados ao retorno ao expressionismo na pintura. 
Lawrence Weiner (na revista Umbrella, v.11, n.1, 1990, transcrito em Hoffberg, 1999, p.141) brincou com o grau de crescimento da circulação no final dos anos 80 , chamando o fenômeno nos Estados Unidos de "Como é Maravilhoso o Livro de Artista". E prossegue: "E o que constitui um livro de artista realmente não importa. Para usar a sentença de Joe McCarthy novamente, 'se anda como um pato e fala como um pato, é um pato". O movimento foi mesmo muito intenso. Ficou estabelecida uma marcante divisão da produção em obras que se comportam como suporte e obras que se comportam como matéria plasmável, o que definirá como bifacetado esse universo. Usualmente, o primeiro caso é o das peças múltiplas, impressas, de construção conivente com a tradição, embora isso necessariamente não ocorra. O segundo grupo é formado pelos livros-objetos propriamente ditos, normalmente peças únicas, fortemente artesanais ou escultóricas, tendentes para o excesso, muitas vezes se comportando como metáforas ao livro, ou ao conhecimento consagrado, ou ao poder da lei. Ou ainda à perseverança formal. Podem ser enquadrados como monstros, se utilizarmos um entendimento conforme o de Omar Calabrese, e de Gilbert Lascault, por ele citado (Calabrese, 1988, p.106). Sobre a fisicalidade do volume, veja, mais adiante, o capítulo sobre espacialidade e corpo.

As características originais do livro-objeto acentuaram o problema de sua definição e da do livro de artista, envolvendo bibliotecários e museólogos em uma renovada rodada de discussões com representantes do sistema das artes visuais. Aqui encontramos o inesperado ponto de indefinição de limites onde este trabalho tenta transitar. Ou seja, dentro do problema plástico que o uso com ou sem violação de um suporte tradicional suscita, existe um outro problema subjacente a ele que é a definição do que a coisa é. E os pesquisadores preferem centrar seus esforços por princípios temporais e históricos. É por isso necessária uma revisão da bibliografia crítica atual.

O material predominante é composto por catálogos de exposições, a maioria com boas ilustrações, alguns com ótimas apresentações, elaboradas por nomes com trânsito nos processos artísticos intermidiais. ${ }^{2}$ Esses catálogos, elaborados às vezes não como obras adicionais, mas paralelas às exposições, além de boas fotos possuem artigos de nomes com bom trânsito nos processos intermidiais, por vezes marginais ao sistema das grandes galerias. Mas são poucos os livros - livros mesmo - dedicados ao assunto.

Um dos marcos fundadores dessa bibliografia foi a publicação em 1985 da coletânea de ensaios e artigos Artists' books: a critical anthology and sourcebook, organizada por Joan Lyons, artista vinculada ao Visual Studies Workshop, nos Estados Unidos. Além dos artigos, o livro, apesar de ser uma pequena brochura, trazia boas fotos, uma ampla bibliografia, com destaque para artigos de periódicos, e endereços de pessoas e entidades ligadas ao livro em todo o mundo. Sendo confirmado o status de campo artístico, surgem os esforços de resenha desse campo. Três grandes compêndios foram lançados

\footnotetext{
${ }^{2}$ Intermedial e intermidial são neologismos. Não constam do Vocabulário Ortográfico da Língua Portuguesa, edição de 1998, ou dos dicionários mais comuns. Optei pela grafia de intermidial, pelo aportuguesamento mídia, do inglês media, do plural latino media, meios. Medial concerne à ideia de centro ou correlatos.
} 
mais ou menos dez anos depois, respectivamente em 1994, 1995 e 1997, se posicionando como a "comissão de frente" da sistematização tipológica. São obras respectivamente de Riva Castleman, Johanna Drucker e Anne Moeglin-Delcroix. Além desses e outros trabalhos que eventualmente serão citados, devem ser destacados os muitos artigos de Clive Phillpot. É impossível falar de livros de artista sem consultá-los.

\section{Riva Castleman: a dívida com a tradição}

A century of artists books (Um século de livros de artistas), 1994, é a principal obra de Riva Castleman sobre esse assunto, publicada para a exposição de mesmo nome, da qual foi curadora-geral, no Museu de Arte Moderna de Nova York, MoMA, entre outubro de 1994 e janeiro de 1995. Nessa grande mostra foram reapresentados 25 dos volumes expostos em 1935 na primeira exposição nos Estados Unidos de livros ilustrados em estilo moderno, acrescentada de mais cerca de duzentos títulos mais recentes. A intenção era mostrar como a presença e/ou interferência do artista visual conformou os "modernos livros de artista feitos na Europa e nos Estados Unidos" através de um período de cem anos (p.12). As obras apresentadas são de edições; não existe a presença de exemplares únicos. O livro e a exposição são instâncias de consagração, mais do que de crítica. Castleman parece ter se colocado numa posição mais conservadora, embora não menos fundamental. Como então diretora do Department of Prints and Illustrated Books, ela mantém uma visão privilegiada dos aspectos museológicos relacionados. Possui vários livros publicados no campo da gravura.

Em obra anterior (Castleman, 1972, segunda edição em 1988, p.206-207), ela já havia esboçado o surgimento do livro de artista:

Referências anteriores foram feitas às muitas edições de luxo ilustradas ou ornamentadas por alguns dos mais notáveis artistas deste século com gravuras nas mídias tradicionais. Os mais casuais livretos dos futuristas russos incluíram impressões feitas em maneiras menos elaboradas que, não obstante, são da maior importância na história dos trabalhos de impressão. O livro de artista [artist's book] que floresceu como uma forma de arte nos anos 70 era uma total obra de arte, preenchida com palavras, fotografias, desenhos e colagens. Seus primórdios provavelmente se originam mais diretamente das várias publicações efêmeras do Fluxus, um grupo internacional de artistas formado no início dos anos 60.

Ela prossegue destacando o livro de artista como um dos "mais importantes subprodutos" da arte conceitual, "para muitos artistas a única expressão tangível”. São citados o norte-americano Edward Ruscha, o "suíço" ${ }^{3}$ Dietrich Roth (Dieter Roth), o belga Marcel Broodthaers, os britânicos Gilbert e George e o escocês Hamish Fulton.

\footnotetext{
${ }^{3}$ Dieter Roth, que também já assinou Diter Rot, é alemão nascido em Hannover, em 1930, mas aparece em algumas obras como suíço ou islandês. Falecido em 1998, dividia seu endereço entre Basileia, na Suíça, e Reykjavik, capital da Islândia.
} 


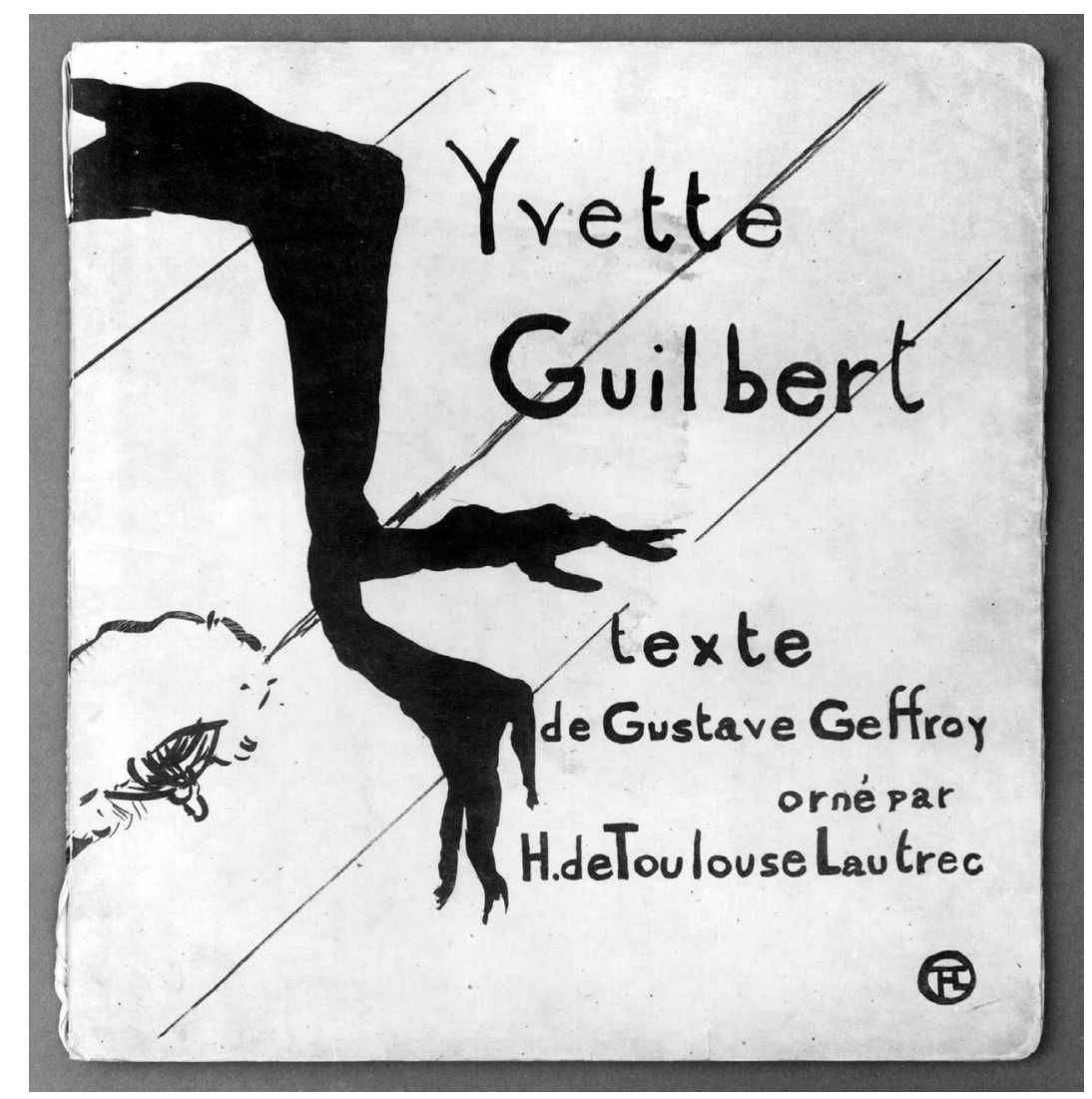

Henri de Toulouse-Lautrec (com texto de Gustave Geffroy), Yvette Guilbert, 1894. Imagem cedida pelo Museum of Modern Art, Nova York.

Em $A$ century of artists books, ela irá relativizar a importância do grupo Fluxus, talvez pelo acesso ampliado a uma maior amostragem da produção do período e ter convivido com as muitas discussões ocorridas nos últimos anos. Mesmo assim, a arte postal não é discutida. Castleman prefere amplos espaços de tempo, também entendendo as colaborações entre artistas e escritores, em particular poetas, como não só fazendo parte dos primórdios, mas já como regular e efetiva produção. Assim, para ela o "moderno livro de artista" é uma obra surgida já na última década do século 19. O termo "moderno" utilizado no seu significado pós-iluminista. Como outros autores, ela diferencia o livro tradicional (o "livro ilustrado" em especial) dos trabalhos dos grandes movimentos artísticos da primeira metade do século 20 e do livro de artista contemporâneo, o qual se constrói a partir da visão totalizadora do seu criador, fortemente ligada aos experimentos conceituais. Nesses termos, destaca Picasso como o maior produtor neste século, com cerca de 150 títulos dos mais variados tamanhos e tiragens, como Temperature, de 1960, com 3,0 x 3,9 cm, ou La Tauromaquia, de 1959, com 34,9 x 49,5 cm. Ressalta, também, a difusão internacional do termo inglês bookwork, gerando novas considerações classificatórias, mas sem aprofundar o problema. Acrescento que no caso do Brasil bookwork 
gerará a denominação livro-obra, antes frequente mas agora já em desuso. Por exemplo, o Livro-obra, 1964-1983, de Lygia Clark, ou nas considerações de Julio Plaza (1982). Mas na língua inglesa bookwork é usado também para trabalhos artesanais dentro do campo de atuação da encadernação e do que denominamos a "arte do livro".

Os caprichos, de Francisco de Goya (Madri, 1799), com águas-fortes e águas-tintas, e Fausto, de Goethe, com litografias de Eugène Delacroix (Paris, 1828), são apontados como uma reação às edições especiais ilustradas de então, se constituindo numa definitiva mudança de atitude dos artistas rumo ao trabalho com o livro. Outras experiências se seguiriam a essas, frequentemente na forma de portfólios. Novo salto seria dado na década de 20 com a possibilidade (viabilidade) de impressões coloridas tonais, graças ao uso de retículas fotográficas. Teriam sido marcos desse processo Ecce Homo, de George Grosz (1923), e Noa Noa, de Paul Gauguin (edição fac-símile de 1926). Albert Skira, na Suíça, criaria, após a Segunda Guerra, o hoje consolidado mercado de "livros de mesa", ambiciosos livros de luxo possibilitados pelas modernas técnicas de impressão colorida, e que atendiam a um público ávido por "belas-artes". Seu sócio na revista Minotaure, Efstratios Tériade, grego, foi o editor de Jazz (1947), de Henri Matisse, e Cirque (1950), de Fernand Léger, ambos trabalhos com projetos gráficos integrais, com gravuras dos autores combinadas com seus próprios textos manuscritos. Ainda segundo Castleman, o mais antigo livre d'artiste (grafado em francês no original) no sentido moderno poderia ter sido um de dois: ou Yvette Guilbert (1894), com texto do jornalista Gustave Geffroy e litografias de Henri de Toulouse-Lautrec, editado em Paris por André Marty (de L'Estampe Originale), por alguns considerada uma obra menos amadurecida; ou Parallèlement (1900), com poemas de Paul Verlaine e litografia de Pierre Bonnard, editado em Paris por Ambroise Vollard.

Castleman entende que o livro de Bonnard é devedor do livro de Toulouse-Lautrec. Chama o território dos livros de artista de bedeviled (p.29), que tanto pode ser enfeitiçado e fascinante, como atormentado e maltratado. Associa o surgimento do novo conceito de livro de artista à emergência de publicadores na Europa e Estados Unidos durante os anos 60 .

Um novo conceito de livros de artistas, que coloca a totalidade do objeto livro no controle criativo do artista, surgiu quase ao mesmo tempo, e as edições limitadas finamente impressas com águas-fortes e litografias adquiriram um diferente significado nesse contexto. Tais livros de luxo, junto com o gênero de livro impresso que emergiu do final do século dezenove, continuam a representar a tradição então iniciada, seus publicadores tão seletivos se não arrojados. Se, como muitos editores do final do século 20 preferem, artistas desenhavam e pintavam suas páginas ao invés de produzirem repetidas impressões para elas, a forma do livro parece estar em seu caminho de volta para uma origem como manuscrito, no momento em que o computador produziu uma outra, mais prática forma de transportar palavras e imagens. (p.37)

Ainda observa que "ao menos até recentemente" a maioria dos livros de artista era publicada na França, a partir da efervescente parceria entre artistas plásticos e escritores (p.37). 


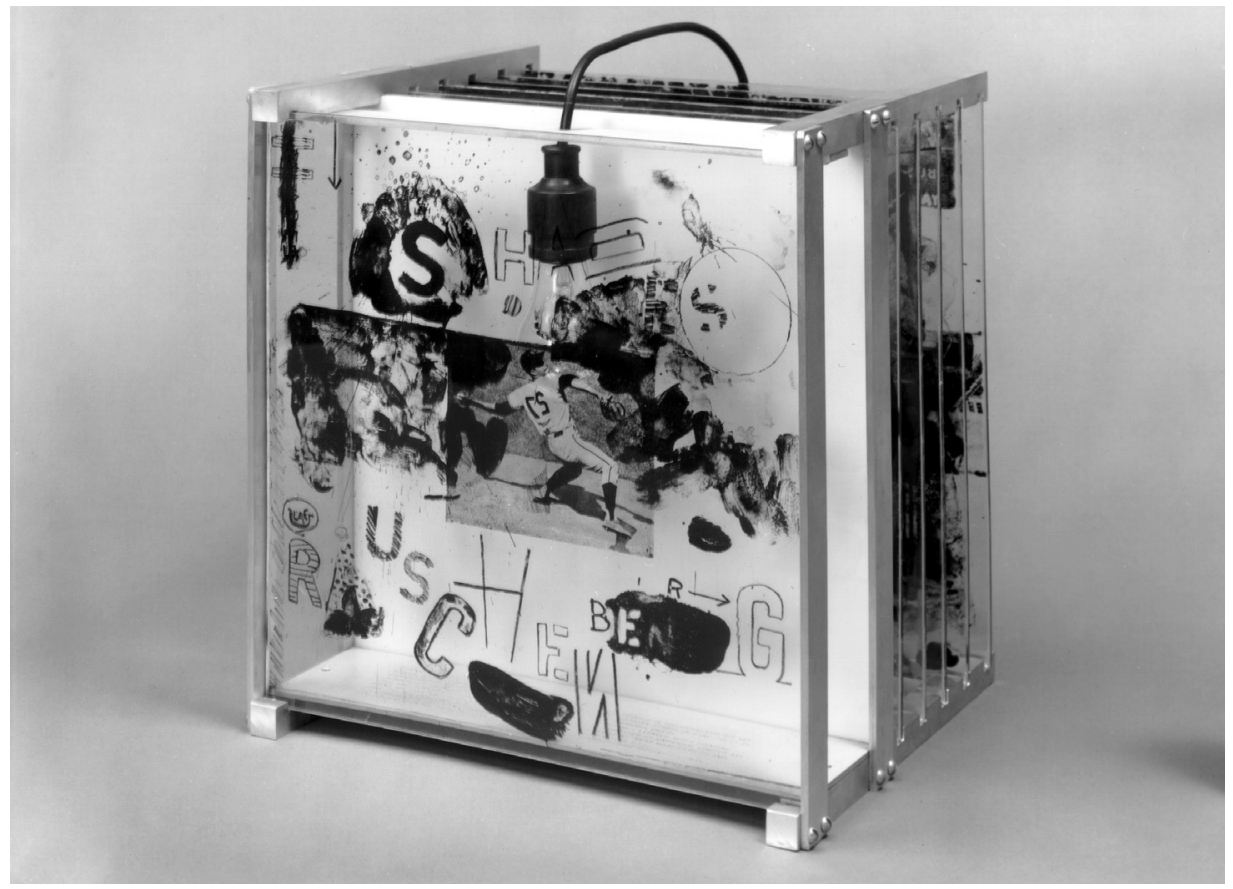

Robert Rauschenberg, Shades, 1964. Imagem cedida pelo Museum of Modern Art, Nova York.

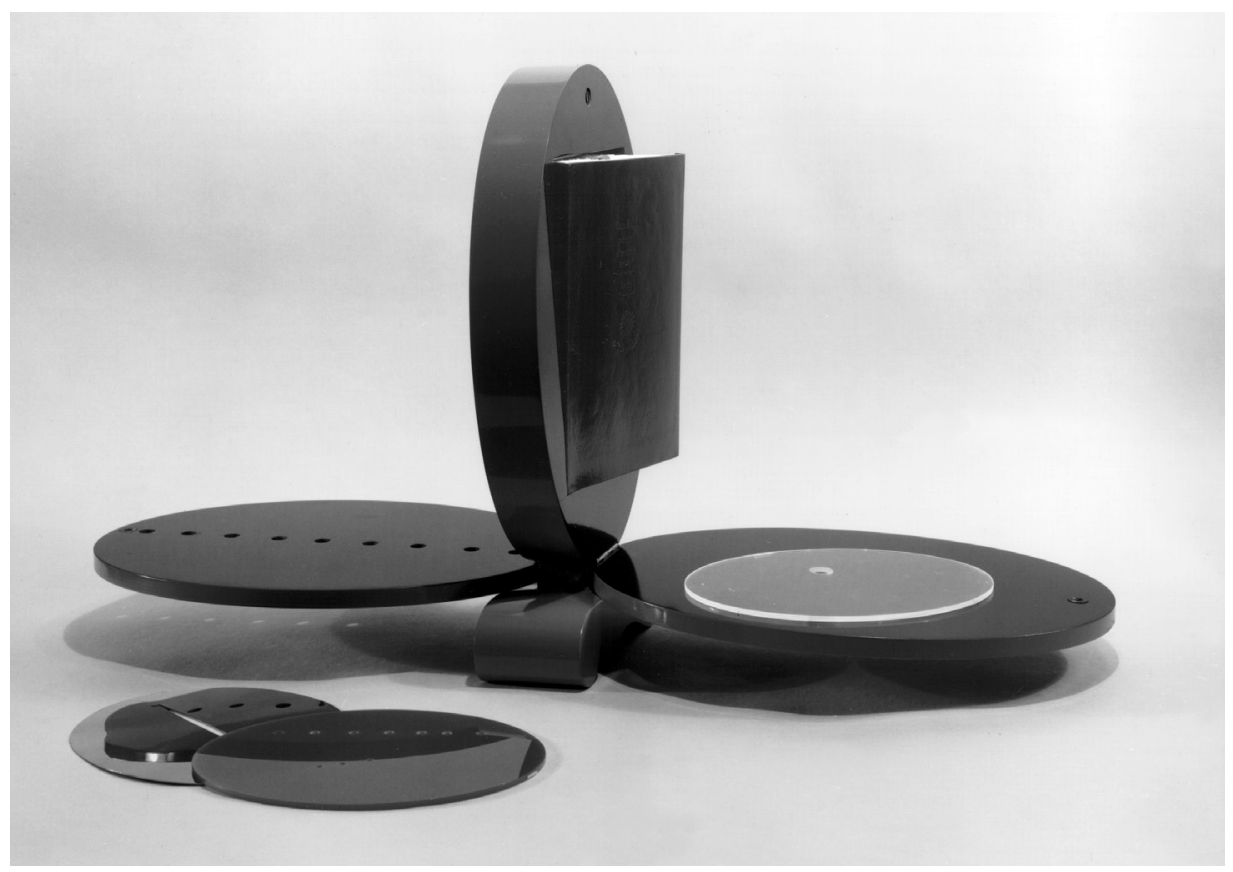

Lucio Fontana, Portrait d'Antonin Artaud, 1968. Capa para livro de Otto Hahn. Imagem cedida pelo Museum of Modern Art, Nova York. 
A aproximação aos trabalhos é feita por grupos. O primeiro, "artistas com autores", é composto pela junção ou justaposição de obras de artistas com textos preexistentes, contemporâneos ou não um ao outro. O segundo grupo, "artistas como autores", é formado por obras cujo próprio artista é o autor. O terceiro, "artistas para autores", é o das obras por encomenda, em que o artista ilustra ou ilumina um texto preexistente, muitas vezes a convite de um editor. O quarto e último, "artistas sem autores", é dos livros ou álbuns com não mais do que legendas ou títulos, quase puramente visuais.

Para o segundo grupo, Castleman registra que "a Caixa verde é simultaneamente o modelo para os assim chamados livros-objetos (aqueles trabalhos do último quarto do século 20 que incluem textos em contêineres não tradicionais) e o mais valioso protótipo para o livro de artista, como veio a ser identificado depois dos anos 50" (p.42). Mais adiante ela retoma o conceito: "livros de artista são isso - a obra do artista cujo imaginário, mais do que estar submetido ao texto, supera-o por traduzi-lo dentro de uma linguagem que tem mais significados do que as palavras sozinhas podem transmitir" (p.50). E discutindo os livros do alemão Dieter Roth, feitos na Islândia nos anos 50 e começo dos 60 , enquadrados no último grupo: "foram os primeiros no desenvolvimento do que seria mais tarde internacionalmente cognominado bookworks. Eventualmente, os artistas conceituais fizeram o livro de artista seu principal objeto de criatividade" (p.52).

\section{Johanna Drucker e a defesa do contemporâneo}

Johanna Drucker é artista e escritora, criadora de livros de artista e professora universitária nos Estados Unidos. Sua pesquisa teórica parece ser herdeira direta das insatisfações geradas pelo livro de Castleman. Irônica, quando não incisiva, fez do título de seu trabalho um imediato enfrentamento ao outro. The century of artists' books ( $O$ século dos livros de artistas), de 1995, se posiciona como contraponto, o primeiro estudo "de corpo inteiro", mantendo vivo o embate conceitual.

Para Drucker, o livro de artista é uma empresa exclusiva do século 20, mesmo que devedor das experiências anteriores, ou seja, do que ela chama livres d'artistes, identificados com valores burgueses das escolas francesas. Primeira frase de seu livro (p.vii): "Livros de artista alcançam a maioridade no século 20." Repete mais adiante que é "a forma de arte por excelência do século 20", com muito poucas ocorrências no século passado (p.1). Nota que uma única definição do termo seria altamente enganosa. Livre d'artiste quando grafado em francês significa livro ilustrado, e é esse termo que tem gerado confusão. Lembra o papel dos empreendimentos editoriais de Ambroise Vollard e Daniel-Henry Kahnweiler na década de 1890 e seguintes na consagração do livro de luxo, o livre d'artiste histórico (p.3). Ele foi uma inovação radical do final do século 19, mas acabou por ter "morte cerebral pela codificação de suas convenções" (p.15). 
Esses livros são trabalhos finamente produzidos, mas eles param antes de ser livros de artista. Eles param no limite do espaço conceitual em que os livros de artistas operam. Antes de tudo, é raro encontrar um livre d'artiste que interrogue a forma conceitual ou material do livro como parte de sua intenção, interesses temáticos ou atividades de produção. Isso é talvez um dos mais importantes critérios de distinção das duas formas, uma vez que livros de artistas são quase sempre autoconscientes sobre a estrutura e significado do livro como forma. (p.3-4)

E acrescenta mais adiante:

Enquanto muitos livres d'artistes são interessantes ao seu próprio modo, eles são produções mais que criações, produtos mais que visões, exemplos de uma forma, não interrogações sobre seu potencial conceitual, ou formal, ou metafísico. (p.5)

Além disso, observa seu papel político na mudança de consciência, como em outras formas simbólicas, o que normalmente não acontece no livro ilustrado clássico. Afirma ser difícil de encontrar um movimento artístico do século 20 que não tenha o seu vínculo com o livro, além de haver muitos artistas com dedicação primordial ao livro. Apesar disso, "o livro de artista, como gênero, ainda não foi examinado, sistematizado ou criticamente incorporado à história da arte do século 20" (p.9). Ela mesma, no seu próprio livro, observa que as obras que ela comenta são tratadas como livros e como exemplos de envolvimento artístico mais do que como atributos ou diretrizes dos movimentos a que os artistas estão associados.

Drucker considera temerário o clichê de outros comentaristas de estabelecer arbitrariamente um marco de origem do livro de artista.

Refere-se a Twentysix gasoline stations, de Edward Ruscha, com primeira edição de 1962. Considera também que existem fortes precedentes do futurismo russo ao surrealismo, indo até as vanguardas norte-americanas. Para ela, o livro de artista precisa ser compreendido como uma "forma altamente mutável". Portanto, não se deveria balizar um julgamento a partir de critérios formais simples ou reducionistas. Ela prefere entender o livro de artista como um campo "que emerge com muitos pontos

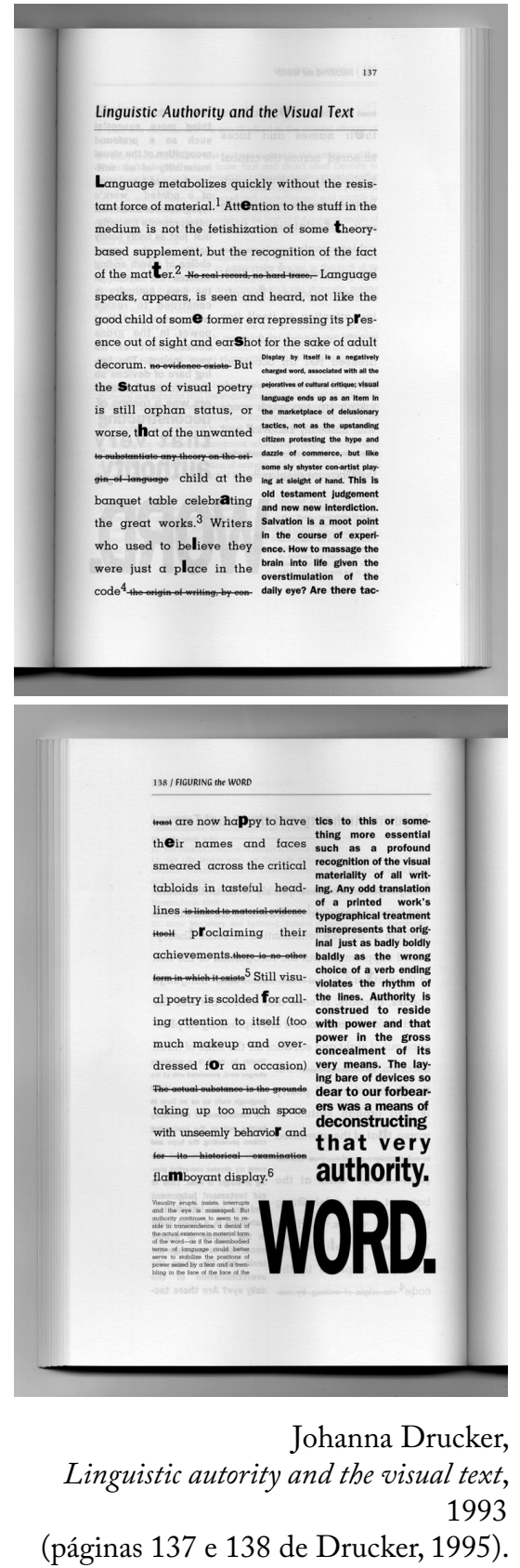

(páginas 137 e 138 de Drucker, 1995). 
espontâneos de origem e originalidade [...] que dá a ideia falsa de uma noção linear de uma história com um único ponto de origem" (p.11). Se os anos 70 marcam a maioridade, é no final da década que uma outra área de atividade relacionada ao livro se desenvolve de forma inequívoca. Trata-se de objetos assemelhados ao livro ou aos livros escultóricos. Eles tiveram poucos, porém notáveis precedentes, como o catálogo Favor tocar (com um seio de borracha porosa na capa), e a Caixa verde (com a documentação do processo construtivo do Grande vidro, ou $A$ noiva despida por seus celibatários, mesmo) de Marcel Duchamp, as caixas de Joseph Cornell e as "salsichas literárias"(feitas com intestino animal recheado com papel retalhado e fervido) de Dieter Roth. Nos anos 80 os trabalhos se direcionam para uma maior proximidade com o conceito da instalação, por um lado, e do vídeo e da realidade virtual, por outro.

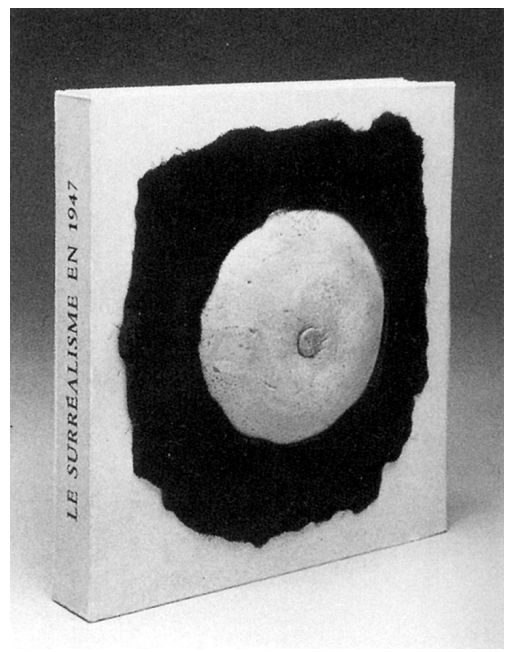

Marcel Duchamp, Prierre de touche, 1947 (foto fornecida avulsa, de fonte ignorada).

Drucker não irá discorrer sobre os livros escultóricos e seus assemelhados. Ela entende que ir além de certos limites diluiria o enfoque dos livros analisados. Além disso, ela está convencida de que esses trabalhos "pertencem mais ao mundo da escultura e da instalação do que ao mundo dos livros. Eles podem operar como ícones do estado de ser livros ou da identidade do livro, mas não proporcionam uma experiência associada com livros mesmo" (p.14). Para Drucker se não é um livro, então não é um livro.

Do ponto de vista dos precedentes históricos, não há muita diferença entre os pensamentos de Drucker e Castleman. Ela destaca a autoconsciência sobre a forma do livro como ponto de partida para a identificação dos precedentes. Como tal, exemplifica com a produção programática dos ingleses William Blake, em fins do século 18, e William Morris, em fins do 19, o primeiro movido pela paixão da fé mística, e o segundo pelo gosto da regra gráfica. Drucker observa que muitas diretrizes têm servido para os livros de artistas como parâmetros a serem inovados ou para desviar dos preceitos de decoro. Livros de artistas, afinal, são distintos das edições de luxo pela negligência ou pela violação de tais regras (p.29).

Como exemplo oposto ao trabalho monumental de Blake e Morris, Drucker apresenta Gelett Burgess, um homem de humor e escracho, algo como o nosso Barão de Itararé. Em São Francisco, na Califórnia, junto com seu amigo Porter Garnett, ele publicou um falso periódico de apenas um número, Le Petit journal des refusées (1896), composto de sátiras à burguesia e refilado em formato trapezoidal. Por tema e forma, o Journal seria um antepassado popular do livro de artista. 
Do ponto de vista da discussão do livro como uma ideia em termos críticos ou filosóficos, Drucker, assim como a maioria dos autores, também destaca o poeta francês Stéphane Mallarmé, autor do poema Un Coup de des (Um lance de dados, 1896), publicado postumamente, e de breves ensaios sobre a poética do livro e da escrita e da ação como evidência da existência. Mas realmente dos trabalhos anteriores ao livro contemporâneo, ela apenas se detém nas vanguardas do século 20 (incluindo algumas menções à poesia concreta no Brasil, citando Augusto e Haroldo de Campos), passando quase imediatamente às obras marcantes de Dieter Roth e Edward Ruscha (nessa ordem), e daí para uma análise dos últimos trinta ou quarenta anos. Quase não há descrição de livros de artista que possam ser classificados apenas como livros ilustrados.

A oposição ao livro e curadoria de Riva Castleman, discreta no título e no texto, é explícita nas notas. Na página 15 , a nota 4 alfineta:

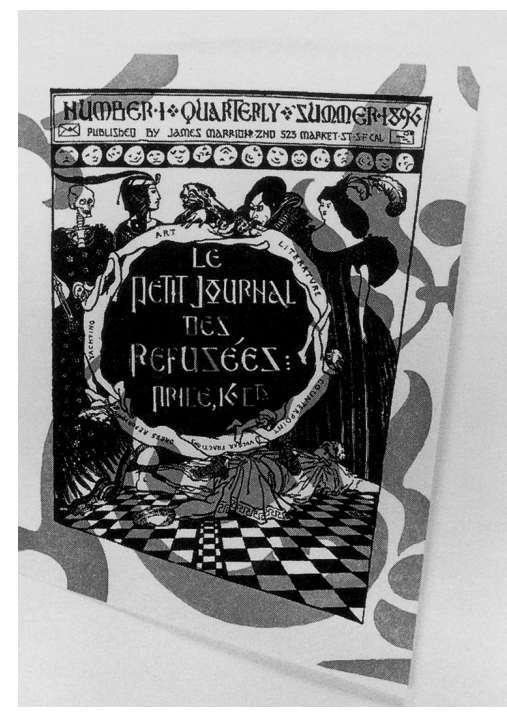

Gelett Burgess, Le Petit journal des refusees, 1896 (Drucker, 1995, p.31).

A exibição erroneamente denominada Um século de livros de artistas [A century of artists books], com curadoria de Riva Castleman, no Museu de Arte Moderna de Nova York, no inverno de 1994-95, é uma seleção representativa de livres d'artiste do século 20. Existem umas poucas anomalias na sua exibição, trabalhos que são livros de artistas, que provavelmente encontram seu caminho para baixo pelo elevador da coleção da biblioteca do MoMA de alguns milhares de livros de artista.

Mais adiante ela volta à carga, na nota 29 da página 90: "A mostra do MoMA com curadoria de Riva Castleman em 1994 NÃO era uma mostra de livros de artista, mas de livros ilustrados, principalmente livres d'artistes". Mas se Castleman foi conservadora, Drucker, por outro lado, optou por não acrescentar livros escultóricos em suas análises e resenhas, apesar de reafirmar que "não existem limites ao que os livros de artista podem ser e nem regras para sua construção" (p.364). Pode-se concluir que essa omissão foi a solução de um problema metodológico.

\section{Anne Moeglin-Delcroix e a estética do livro}

O terceiro nome com produção de compêndio nos últimos anos é o de Anne Moeglin-Delcroix, francesa, professora da Sorbonne, trabalhando com curadoria e coleções de livros de artistas no Cabinet d'Estampes na Biblioteca Nacional em Paris. 
É um dos principais nomes desse campo de estudos na Europa continental. Seu Esthétique du livre d'artiste: 1960/1980 (Estética do livro de artista: 19601980) é fruto de sua tese de doutorado, resultando num exemplar volumoso. Portanto, sua obra tem o privilégio de suceder as outras duas antes citadas, de Castleman e Drucker, ao mesmo tempo em que é subsequente a uma pesquisa iniciada antes. Como brincadeira, pode-se dizer que o único defeito sério em sua obra é o seu não-ingresso nos anos 90 . Será necessário aguardar suas novas publicações.

É verdade que Esthétique... é uma pesquisa de grande fôlego, mas a inserção definitiva de Moeglin-Delcroix no terreno dos debates já havia acontecido em 1985, com um trabalho menor, o catálogo da exposição Livres d'Artistes. Menor mas não menos importante.

No catálogo ela levantou, rapidamente, os problemas e particularidades das expressões livre d'artiste e livre illustré, sendo o livre-objet uma forma particular de livro de artista. Sua explanação se apoiou no pensamento de nomes contemporâneos, como Clive Phillpot, Paul-Armand Gette, Hubert Kretschmer e outros, em cruzamento com a marcante tradição francesa do livro ilustrado. Elege como data de seu nascimento (livro de artista no sentido estrito) os anos 60 , em um fenômeno conjunto aos movimentos de vanguarda, através de dois canais simultâneos, um europeu, e o outro norte-americano. Pela Europa, Dieter Roth, com o trabalho desenvolvido a partir de 1961, com especial destaque para as versões de Daily Mirror até os anos 70; pelos Estados Unidos, Edward Ruscha, em 1962, com a publicação de Trentysix gasoline stations. Esses dois artistas apontariam as direções principais que a atividade seguiria, com grande desenvolvimento nos anos 70: a primeira, de espírito neodadaísta, de exploração multiforme; a segunda, de espírito conceitual, de rigor sistemático. Por minha conta, acrescentaria que essas correntes já existiam historicamente, tendo de um lado o livro de corte dadá-surrealista e, de outro, o livro de concepção diagramático-construtiva. Entre essas correntes, em muitos momentos interpenetrando-as ou com elas se confundindo, o livro futurista. Estaríamos aqui, novamente, encontrando ressonâncias do dualismo clássico e barroco e do gosto conservador eslavo-germânico e latino-mediterrânico? Talvez. Mas o que salta aos olhos é, primeiro, que o Hemisfério Norte ocidental é um grande brique ou um grande caldeirão de museus, do público 
ao privado e ao pessoal; e, segundo, que (não nos esquecendo da participação da Ásia) tiveram a hegemonia do conhecimento gráfico. São fatores muito significativos para a instauração do livro de artista contemporâneo.

O catálogo Livres d'artistes (ou a exposição) se constrói pela busca de uma organização sistematizadora que equilibra o conceito entre a arte e a bibliofilia, mas sem prestar atenção às obras anteriores aos anos 60. Com isso, a autora provoca o rompimento da qualificação livres d'artiste da qualificação livre illustré, afirmando a autonomia da obra plástica de vanguarda da obra de colaboração conservadora. Por um lado ela denega a participação do livro ilustrado na sua exposição. Mas por outro ela alarga sua mostra até o livro-objeto mais radical. Caracteriza, assim, um campo a ser subdividido pelo papel desempenhado pelo livro (e sua ideia como tal) na produção do artista: ou o livro atuará como suporte (o que é apresentado como o usual) ou o livro atuará como objeto (a ponto de deslocar a amplitude de sua demonstração até o livro-objeto, os trabalhos escultóricos e o não-livro).

Anne Moeglin-Delcroix acusa a "significação ampliada" pela vizinhança das acepções de livro de artista e livro-objeto (p.11 e 12). Reconhece duas correntes heterogêneas de livros-objetos. A primeira é a que remonta aos poemas-objetos dos surrealistas e às encadernações de Georges Hugnet (reconhecidos como "livros-objetos"). A segunda corrente, mais recente, "e que só nos interessa do ponto de vista de sua aproximação possível com o livro de artista", se inspira nas colagens da pop art, nas acumulações do novo realismo e nas reutilizações da art povera, e seria um objeto em forma de livro, liberto da origem literária. Embora Moeglin-Delcroix não fale em perversão de uso, ela deixa clara a anulação, nesse caso, da função de leitura. Fala da realidade sensível do material em detrimento do conteúdo de informação. Pode ser presumido que, nesse caso, ela considere como

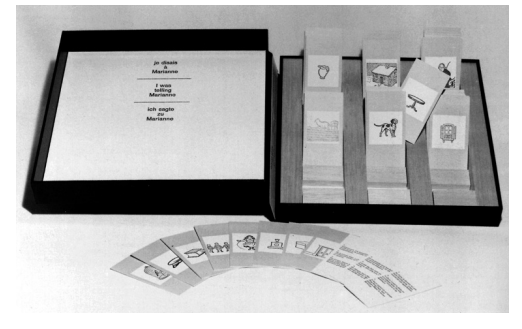

Robert Filliou, Je disais a Marianne, 1965 (Moeglin-Delcroix, 1992, p.76).

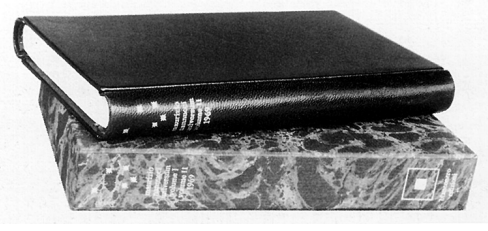

Maurizio Nannucci, Universum, 1969 (Moeglin-Delcroix, 1985, p.116).

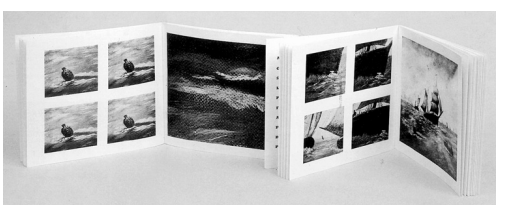

Marcel Broodthaers, Un Voyage en Mer du Nord, Eine Reise auf der Nordsee, A Voyage on the North Sea, 1974 (Moeglin-Delcroix, 1985, p.84-85).

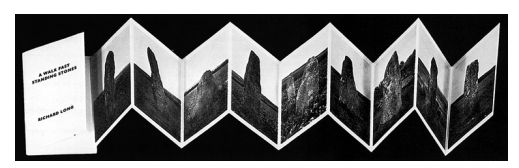

Richard Long, A Walk past Standing Stones, 1980 (Moeglin-Delcroix, 1985, p.74-75). 


\section{LIVRES-OBJETS par GEORGES HUGNET}

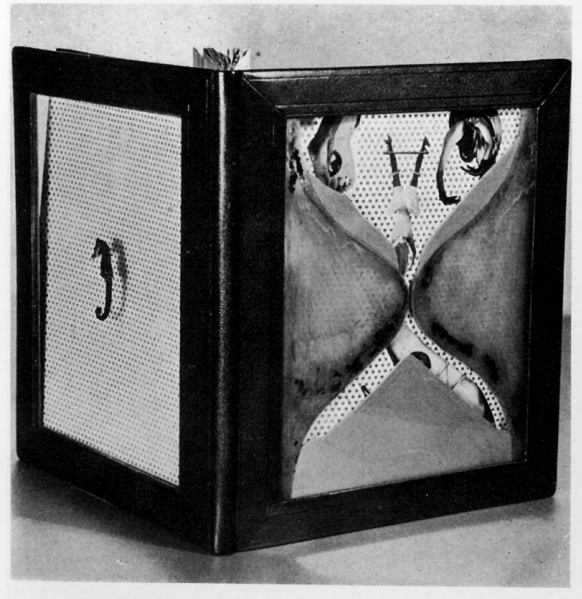

GEORGES HUGNET : ONAN

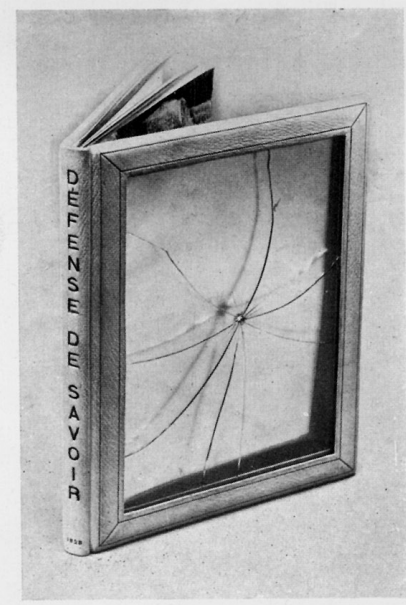

PAUL ELUARD : DÈFENSE DE SAvOTB

PHoto CAILLET

La femme nue et parfaite exalte la femme élégante et savamment maquillée. Les reliures de Georges Huguet - qui sont plutôt des constructions fantômatiques autour des livres - les préparent et les fardent pour le plus grand bal de leur vie. Ainsi, dit-il, "le livre remplit son objet". Il le remplit jusqu'à ce qu'il en éclate, car les vitres s'étoilent

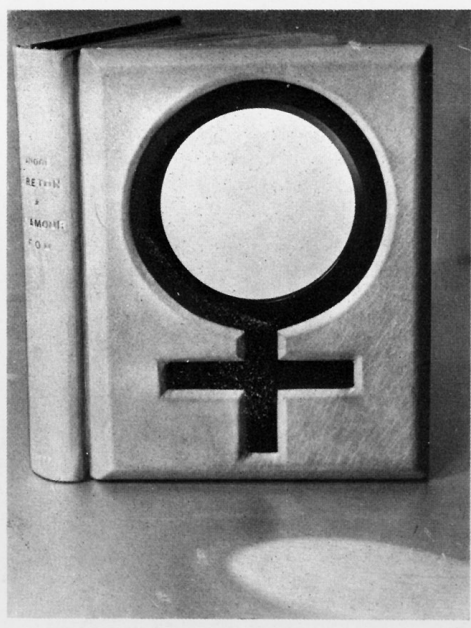

ANDRÉ BRETON : L'AMOUR FOU

PHото UBAC

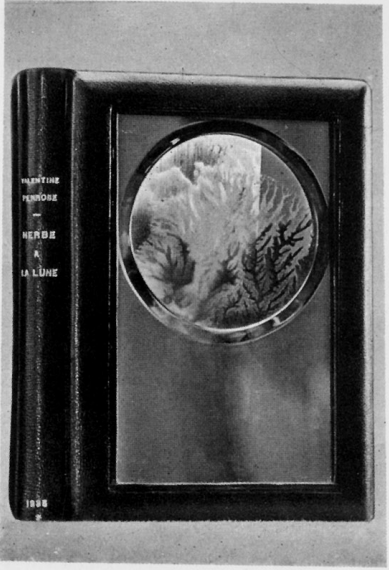

sous les balles tirées de l'intérieur et le mercure, évadé des thermomètres, marque indéfiniment une température caniculaire. Rien ne s'oppose plus à ce que le livre, faisant la roue, entraîne dans son sillage les mille mouettes du désir approchant de son île d'élection.

Benjamin Péret.

Página da revista Minotaure, n.10, 1937. 
informação mensagens de encadeamento lógico, vocalizáveis.

Também devem ser identificados, segundo ela para evitar o rigor dos limites entre livro ilustrado, livro-objeto e livro de artista, os livros híbridos.

Com o seu trabalho de 1997, assuntos referentes à tipificação são estendidos para um melhor desenvolvimento. Ainda assim, um problema persiste: o primeiro capítulo procura responder a eterna pergunta “o que é um livro de artista?". Nele, aproveita para descrever o problema das traduções ou versões entre o francês e o inglês, além da utilização pelo universo anglo-saxão dos termos franceses livore d'artiste, livre illustré e livre de peintre. O problema lexicográfico parece estar incrustado nesse campo. Moeglin-Delcroix designa livre de peintre ao exemplar de luxo, semi-artesanal e caro, inevitavelmente ligado ao consumo burguês. $\mathrm{O}$ capítulo "Um produto de série de primeira ordem” (p.27) qualifica o livro de artista a partir da afirmação de Ruscha, feita em 1965, segundo a qual o livro de artista é que, através de seu trabalho, definiria as características que a produção viria a ter: livros singelos, de edição ilimitada e baixo preço de venda, com reproduções fotográficas frequentemente não estetizantes e impressão offset, propiciando ao artista pleno controle do trabalho. Ela enfatiza a importância da autopublicação e da autodistribuição dentro desse processo, numa caracterização de independência que o afasta da situação de controle e interferência do editor dos tradicionais livros de bibliófilos. $\mathrm{O}$ artista era (ou é) cônscio da possibilidade de acesso à arte pelos meios (mídias) de reprodução. E, muito mais do que fac-similar suas obras, ele passa a conceber a obra como um múltiplo industrial ou semi-industrial. Moeglin-Delcroix, que valoriza as opiniões de artistas, transcreve a proposição de John Baldessari, feita em 1969 (p.33):

Ninguém mais olha para a arte. Obras de arte deveriam ser feitas diretamente para a reprodução em revistas de arte. Já que nós conhecemos as obras por
T W EN T Y SIX

GASOLINE

STATIONS

Edward Ruscha, Twentysix gasoline stations, 1962-1963

(é a primeira foto de Moeglin-Delcroix, 1997, p.18).

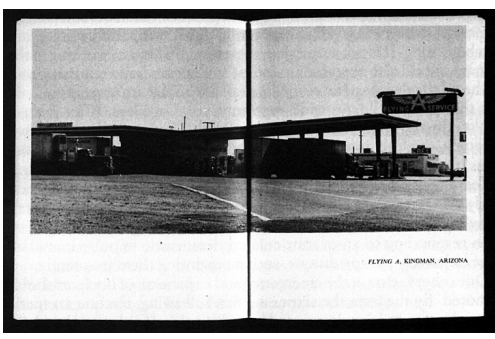

Edward Ruscha, Trentysix gasoline stations, 1962-1963.

A sequência integral de páginas dos livros de Ruscha está reproduzida no catálogo geral de suas obras organizado por Siri Engberg, 1999, também com ensaio de Clive Phillpot.

A imagem mostrada acima é do artigode Phillpot para Artists' books: a critical anthology and sourcebook (p.99), organizado por Joan Lyons em 1985 para o Visual Studies Workshop, em Rochester, Estados Unidos. 
suas reproduções, deveríamos trabalhar unicamente para a reprodução. Não mais arte mediada.

No ano seguinte, Baldessari queimaria a parte principal de suas pinturas e colocaria as cinzas numa urna com forma de livro. Por esse motivo, entre outros, ficaria posto à prova o pensamento de Walter Benjamin sobre o desaparecimento da aura da obra de arte provocada pela reprodutibilidade.

A esse respeito, a reflexão benjaminiana sobre o desaparecimento da aura ligada à reprodução não mais permite entender uma situação tornada mais complexa. A sociedade contemporânea instaurou um acesso coletivo às próprias obras, favorecido por uma política de exposições bem sucedidas que as transformou em acontecimentos culturais; ora, tal "massificação da aura" é absolutamente o contrário de uma democratização da arte, uma vez que nela se perde a experiência estética em prol de uma vaga cultura artística em que o museu serve para verificar a imagem das obras-primas tornada familiar através da reprodução. Segundo uma lógica inversa, o livro de artista possibilita paradoxalmente um acesso público e, não obstante privado, secreto, aurático, à reprodução na medida em que aí o processo de reprodução é aquilo que produz a obra. Ainda mais, o livro oferece esta sob a forma a mais autêntica uma vez que a mais protegida de toda subordinação a interesses comerciais. Novamente, John Baldessari descreve a intenção através da qual estes livros, entre os quais os seus, são concebidos: "A arte parece pura por um momento e desligada do dinheiro. E como muitas pessoas podem possuir o livro, ninguém é dele proprietário." O que, através da reprodução e multiplicação, teria podido afastar a arte de sua essência é, ao contrário, aquilo que a aproxima da mesma. ${ }^{4}$ (p.33-34)

Enfim, se o produto de consumo é um livro, não há conflito entre atingir o maior número possível de leitores como um todo e, simultaneamente, atingir cada um individualmente, já que a leitura é geralmente uma experiência solitária. "Tal atitude participa mais fundamentalmente no antiformalismo

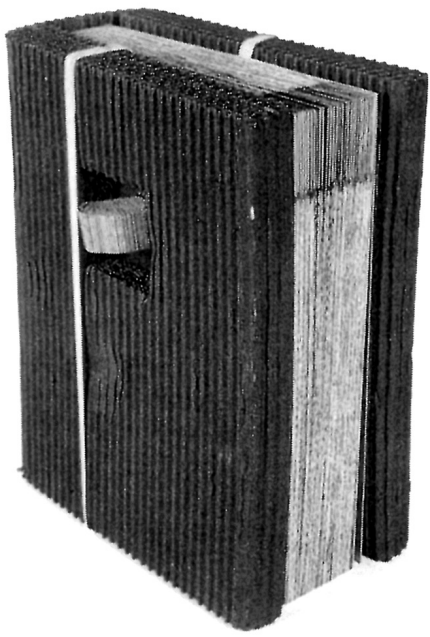

Dieter Roth, Daily Mirror, 1970.

(Moeglin-Delcroix, 1985, p.12.)

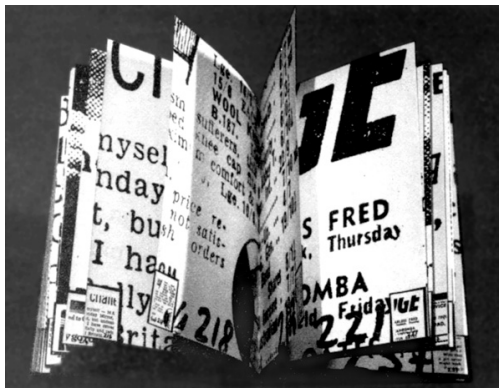

Dieter Roth, Daily Mirror, 1970, na exposição Books by Artists, 1981, organizada por Art Metropole, de Toronto. O espaço, de discussão e difusão de arte acessível, foi pioneiro nos anos 70, junto com Other Books \& So, em Amsterdam, e Printed Matter, em Nova York. Foi criado pelo grupo General Idea, formado por AA Bronson, Felix Partz e Jorge Zontal.

${ }^{4}$ Traduzido por Robert Ponge. 
inerente aos livros de artista" (1t ArtistBook..., 1994, p.33). Essas e outras considerações compatibilizam as conclusões de Anne Moeglin-Delcroix com a técnica mais do que com o artesanato. Se os livros-objetos matéricos ou escultóricos tinham mais espaço na exposição de 1985 (o que provavelmente era fruto de uma evidência), no livro e exposição de 1997 eles têm uma presença mais discreta. Entretanto, agora ela se detém com muito maior precisão nos conceitos e suas traduções.

Para Moeglin-Delcroix, o mais importante (e definidor) produtor de livros de artista é Ruscha, por entender que seus trabalhos realizaram uma ruptura maior que os de Roth. Os primeiros trabalhos de Roth estavam muito relacionados com o construtivismo abstrato suíço dos anos 50, não tendo, por isso, o caráter revolucionário dos de Ruscha. Ela acredita serem os livros de Ruscha o melhor de sua obra artística. Quanto a Roth, ela afirma preferir seu trabalho plástico, embora tenha a conviçção de que Daily Mirror Book, Snow e 246 little clouds sejam obras-primas do gênero (JAB 6, 1996, p.12).

Eu penso que o livro é, tanto historicamente como por sua natureza, um meio concebido para conferir prioridade à mensagem. Essa é uma das principais razões para seu aparecimento [no mundo da arte] nos anos 60: a rejeição do formalismo artístico, naquele momento dominante na prática criativa e crítica, em favor de uma arte cujo alvo era significar (para modificar hábitos de pensamento) ou intervir no mundo e na vida real (para mudá-la). Em resumo, o livro, por sua verdadeira natureza, parece para mim ser o meio idealista (visível) por excelência! O suporte material não tem que ser levado em conta exceto na medida em que isso contribui para o conteúdo. (Anne Moeglin-Delcroix: response to Johanna Drucker. $J A B$ 6, 1996, p.13)

Eis outro possível motivo para a não inclusão de livros matéricos no seu livro de 1997.

\section{Clive Phillpot, o resto do mundo e Phillpot de novo}

No estudo do esforço fim-de-século de compreender a evidência da arte em formato livro, o que se constata é que curiosamente persiste o problema da definição do que a coisa é. Note-se que nos casos anteriores existe sempre um isso-é-isso-não-é, baseado ou em valores estabelecidos ou em valores em estabelecimento. Mas na maioria dos casos, quer em textos americanos (pan-americanos), quer em textos europeus, um nome permanece indo e vindo, sempre na condição de definidor dos principais pontos de partida para a definição do problema, ora propondo parâmetros, ora construindo paradigmas.

Antes do lado de cá do Atlântico, agora do lado de lá (vive na Grã-Bretanha), Clive Phillpot tem sido o mais influente nome, a partir de sua experiência por muitos anos na direção da biblioteca do Museu de Arte Moderna de Nova York (onde constituiu a maior coleção mundial de livros de artista), como crítico de arte, e de sua ligação com Printed Matter, revendedora e agente cultural nova-iorquina criada em 1976 por Sol LeWitt e Lucy Lippard, entre outros. Atualmente é consultor da Biblioteca de Artes 
Visuais do British Council. Atribui a Ruscha o principal crédito em demonstrar que o livro pode ser um veículo primário para a expressão artística individual. Faz o elogio das edições ilimitadas, não assinadas e não numeradas, acessíveis não apenas em galerias, mas também em livrarias, quebrando a aura fortemente institucionalizada do objeto precioso. Quanto a Dieter Roth, Phillpot antecipa sua entrada em cena com as criações geométricas dos anos 50, em particular Children's book, iniciado em 1954, e publicado em 1957 na Islândia.

Um artigo seu particularmente importante foi "Books, book objects, bookworks, artists' books", publicado na revista Artforum de maio de 1982, a propósito de Real Lush, de Kevin Osborn. Nele, Phillpot amplia o conceito ainda em estabelecimento de "livros feitos por artistas" para "feitos ou concebidos por artistas" (p.77). Leva em consideração a eventual presença de outros profissionais no apoio ao artista. Apesar disso, ele se sente desconfortável com definições que incorporam a qualificação "de artista”. Reconhece, entretanto, a tendência das artes visuais contemporâneas serem categorizadas pela sua mídia: vídeo-arte, body art, arte postal, performance, instalação, etc. Entende que existiam dois motivos para o estabelecimento e aceitação do termo livro de

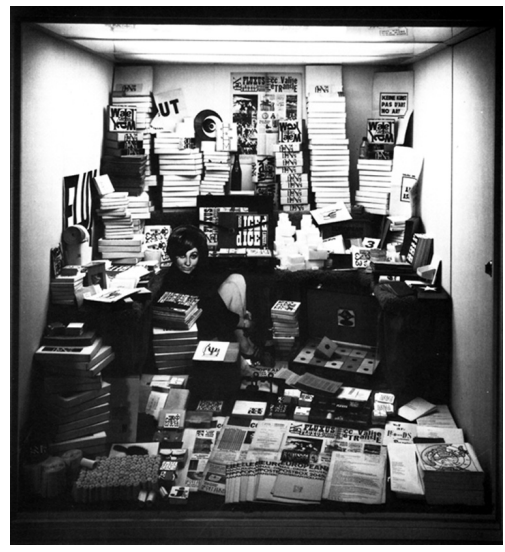

Vitrine Fluxus. (In: Phillpot e Hendricks, 1988.)

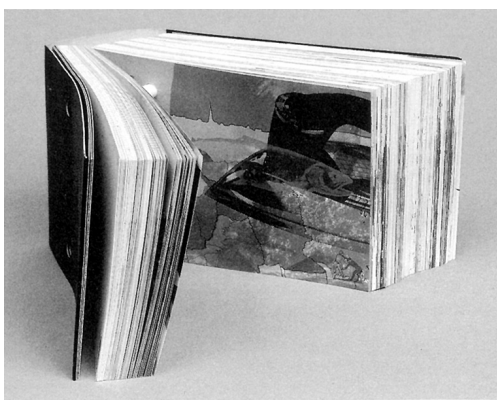

Kevin Osborn, Real lush, 1981. (Moeglin, 1985, p. 85.) artista. A primeira era de que "existia a necessidade definida de demarcar território que excluísse a moribunda tradição da 'arte do livro', assim como da indústria do livro de arte". Segundo, "havia a sugestão implícita de que os livros de artistas eram somente uma linha secundária para artistas cuja principal atividade era, por exemplo, pintura ou escultura”. Phillpot lembra Ulises Carrión e seu entendimento para a palavra bookworks, que seriam "livros em que a forma do livro, uma sequência coerente de páginas, determina condições de leitura que são intrínsecas à obra". ${ }^{5}$ Aponta para o uso de artists' books, tanto para exemplares impressos, como para exemplares únicos, os livros-objetos, que enfatizam a fisicalidade do volume. Livros múltiplos ou únicos se diferenciam não apenas pelo aspecto, mas também pela filosofia de seus criadores. Enquanto os primeiros buscam o acesso universal, os outros rejeitam

\footnotetext{
${ }^{5}$ Phillpot se refere a "Bookworks revisited", em The Print Collector's Nerwsletter, v. 11, n.1, março-abril de 1980, p.8. Essa palavra não tem tradução adequada para o português, um idioma que não tem as mesmas facilidades para neologismos como o inglês. Usou-se, mas sem permanência, o termo "livro-obra", como no título de um trabalho de Lygia Clark, citado mais adiante.
} 
o potencial de proliferação. Para Phillpot, os livros múltiplos são cada cópia uma obra de arte.

Livros-objetos frequentemente apenas se parecem com livros - eles podem ser objetos sólidos que não podem ser abertos, permitir leitura solitária; eles se tornam escultura. Livros únicos podem ainda ser livros-obra [bookworks] quando, por exemplo, o único protótipo de um livro múltiplo é virtualmente idêntico a uma das muitas cópias que gera, e portanto divide essas propriedades de múltiplo, exceto somente sua disponibilidade.Múltiplos livros-obras, ao contrário de livros de artistas múltiplos, não são tão comuns quanto se pode supor. Poucos fazedores de livros produzem trabalhos que são realmente dependentes da forma do livro. Muitas pessoas agrupam páginas juntas, mas poucas concebem seu trabalho nos termos do meio. (p.77)

Phillpot ilustra o seu artigo com um diagrama em que propõe interseções ou áreas comuns ao campo dos livros comuns, dos livros de artista e da arte. $\mathrm{O}$ livro de artista pode ser apenas um livro convencional, pode ser um livro-objeto, ou pode ser um livro-obra, pertencendo tanto à arte como à bibliofilia. Em todos os casos eles podem ser únicos ou múltiplos. $\mathrm{O}$ diagrama fez sucesso e foi algumas vezes republicado.

Em dezembro de 1982, Art Documentation, o boletim da Sociedade das Bibliotecas de Arte da América do Norte (Art Libraries Society of North America), dedicou seu número ao esclarecimento do assunto para o público bibliotecário, incluindo problemas técnicos e financeiros. Phillpot foi o coordenador do grupo de artigos, denominado $A n$ ABC of Artists' Books Collections. Em mais um esforço de clareza, a capa apresentava, ao invés de uma previsível ilustração, apenas a transcrição dos conceitos de book, art book, artist's book, book art, bookwork e book object.

livro. Coleção de folhas em branco e/ou que portam imagens, usualmente fixadas juntas por uma das bordas e refiladas nas outras para formar uma única sucessão de folhas uniformes.

livro de arte. Livro em que a arte ou o artista é o assunto.

livro de artista. Livro em que um artista é o autor.

arte do livro. Arte que emprega a forma do livro.

livro-obra [bookwork]. Obra de arte dependente da estrutura de um livro. 
livro-objeto. Objeto de arte que alude à forma de um livro.

É importante registrar que isso fez parte da intensa movimentação do início dos anos 80 , especialmente 1981 e 1982, num momento de maioridade do livro de artista. Correndo em paralelo com a arte postal, com a qual compartilhava grande parte de seus criadores, o livro de artista alcançou os principais recantos do mundo. Isso se deu, por um lado, pela extrapolação de fronteiras permitida pela multiplicação do original, e, por outro, pela possibilidade de qualquer artista, independente de sua habilidade artesanal, elaborar uma peça única, conforme ou não ao livro. Assim, pequenas, médias e grandes exposições coletivas aconteceram na França (ainda com débito ao livro ilustrado), Itália (um pouco dependente da poesia visiva), Alemanha e Holanda (com posturas mais críticas). Nos Estados Unidos, de costa a costa foram algumas dezenas de mostras de todos os tamanhos, afirmando o país como o maior produtor e disseminador. No Canadá, patrocinada

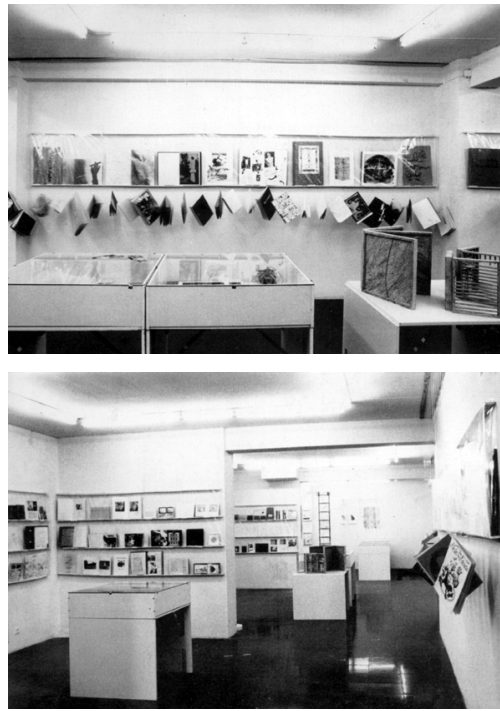

Llibres d'Artista/ Artist's Books, 1981, exposição no espaço Metrònom, Centre de Documentació d'Art Actual, Barcelona, organizada por Rafael Tous (imagem reproduzida da página de rosto do catálogo) por Art Metropole, de Toronto, a mostra Books by Artists percorre o país em seis exibições entre 1981 e 1982. No México, em 1981, após uma importante mostra na Califórnia, Estados Unidos, o Museu de Arte Moderna dedica um número duplo de sua revista Artes Visuales a um levantamento da singular produção mexicana. No Brasil, a XVI Bienal de São Paulo, em 1981, apresentou uma grande exibição de arte postal com curadoria de Julio Plaza, com um setor ("vetor A-2") dedicado ao livro de artista. Mas entre as mais influentes exposições desse mesmo ano estava a organizada pelo espaço Metrònom, de Barcelona, Espanha, Llibres d'Artista/Artist's Books, com organização de Rafael Tous i Giner: de todo o mundo participaram mais de oitocentos artistas com cerca de 2 mil trabalhos. Todos esses eventos motivaram, confirmaram e reconheceram a existência de uma multiplicidade formal muito mais agressiva que a dos anos 60. Embora a marginalidade do livro de artista continuasse preservada, as definições tradicionais (do conceitualismo dos anos 60 e 70) não davam mais conta de sua tarefa. Alie-se a isso a transferência das expressões francesas livre de peintre, livre de luxe e livre d'artiste para a língua inglesa, que absorve com objetividade os estrangeirismos. Isso criou, como já foi visto, e ainda cria, muita confusão. É o caso de lembrar que uma edição de luxo, de tiragem limitada, na tradição britânica privilegia o texto tipográfico, enquanto a tradição francesa privilegia a ilustração que o acompanha, independente do fato de ambas apresentarem os mesmos requintes de encadernação (Hill, 1984). O Canadá vivenciou 
esse problema conceitual por sua particular situação de paralelismo cultural aos falares francófonos e anglófonos. Ver, por exemplo, a evolução do nome e dos acervos das exposições Made in Canada, organizadas pela Biblioteca Nacional do Canadá. Da primeira, realizada em 1981, até a quinta, em 1987, seu subtítulo era Artists in Books/Livres d'artistes. Apenas na sexta edição, em 1990, houve a mudança para Artists' Books/Livres d'artistes. Simultaneamente a isso, a Biblioteca Nacional do Quebec constituía a sua coleção de livros de artista, subdividida em três categorias: edições de luxo limitadas, livros-objetos e edições de tiragens abertas (Les collection..., 1996, p.48 e seguintes). O reconhecimento da fundação de uma categoria artística passível de catalogação no Canadá pode ser encontrado no estudo independente de Peter Trepanier, Artists' books? A definition and na argument for their inclusion in library collections, 1983, para a McGill University. Trepanier é atualmente diretor da Biblioteca da National Gallery of Canada/Musée des beaux-arts du Canada. Ele observa que a Biblioteca do Congresso já teria reconhecido o assunto artists' books (p.14). ${ }^{6}$ Mas como colocar sob a mesma rubrica um folheto em sanfona, um grosso volume de mais de mil páginas em branco ou um cepo de madeira? E afinal, que parâmetros utilizar na decisão do local adequado para o livro-objeto, se na galeria (ou museu), na biblioteca, ou em ambos? A realidade é que o problema estava só no seu começo oficial.

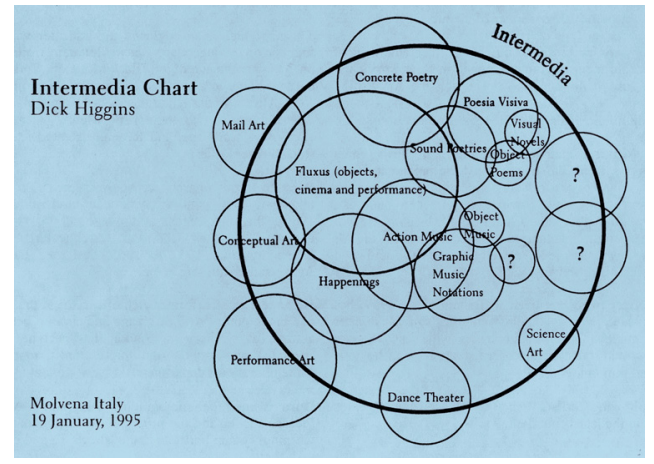

Dick Higgins, gráfico da intermídia (Umbrella, v. 20, n. 3/4, outubro de 1997, p. 96).

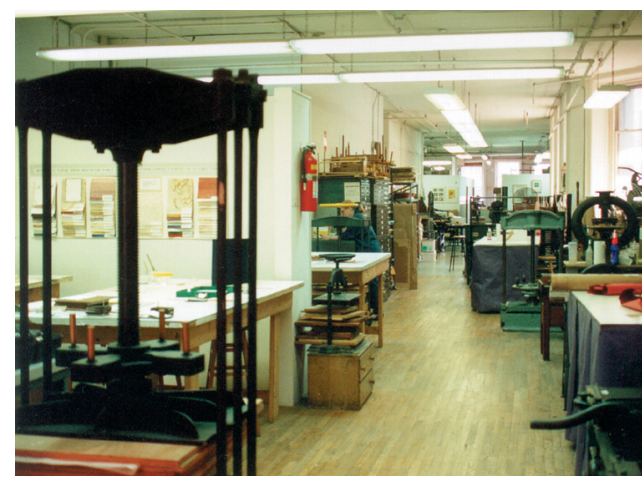

Antigas instalações do Center for Book Arts, em Nova York, fundado em 1974 por Richard Minsky. Em 1999 mudou-se para nova sede, graças a fundos próprios e donativos.

Seus programas de cursos informam que o centro "é dedicado à preservação dos ofícios tradicionais da feitura de livros, bem como encorajar interpretações contemporâneas do livro como um objeto de arte". E costumam acrescentar um alerta para os alérgicos: "O Center for Book Arts é o lar de Lizzie, a gata”.

\footnotetext{
${ }^{6}$ No Brasil, Muriel Scott, bibliotecária chefe da Seção de Obras Raras e Especiais da Biblioteca Mário de Andrade, em São Paulo, seção onde os livros de artistas são incluídos, informa que a coleção cresceu recentemente com doações de Haroldo de Campos. Essas obras estão sendo catalogadas e estarão disponíveis como "livros de artistas".
} 
A continuação (também oficial) do problema, ocorreu em 1993, no Art Libraries Journal, periódico internacional para bibliotecários de artes visuais, com sede principal na Grã-Bretanha. ${ }^{7}$ No número 1 , volume 18 , a revista dedicaria suas primeiras 28 páginas para questões semelhantes. Clive Phillpot foi solicitado a contribuir com o texto de sua apresentação em uma conferência europeia de bibliotecas de arte. O resumo de seu texto esclarece (Twentysix gasoline stations that shook the world: the rise and fall of cheap booklets as art, p.4):

O termo "livros de artista" tem sido usado desde cerca de 1970 para denotar livretos de baixo preço produzidos por artistas em tiragens "ilimitadas", mas pode legitimamente abarcar uma variedade de artefatos; a palavra "livro-obra", cunhada em 1975, carrega consigo o significado mais específico de uma obra de arte em forma de livro. Twentysix Gasoline Stations, de Ed Ruscha, publicado em 1963, foi um livro-obra pioneiro; foi seguido por mais livros-obras do mesmo artista através dos dez anos seguintes; entretanto, as produções inovadoras de Ruscha foram precedidas por um número de experimentos com o formato livro, por Bruno Munari, Âke Hodell e outros, durante os anos 50 e início dos 60. Livros-obra floresceram nos 70 como um meio de produzir verdadeiras obras de arte disponíveis para uma ampla audiência, mas nos 80 esse ideal foi gradualmente ultrapassado por uma crescente tendência no sentido de se fazer livros-obras como preciosos, custosos colecionáveis, em edições limitadas, enquanto alguns dos anteriores, uma vez baratos livros-obras, passaram a ser vendidos por preços inflados no mercado de livros usados. Todavia, muitos artistas estão prosseguindo a produzir livros-obras relativamente acessíveis, às vezes usando fotocopiadoras, ou a publicar revistas de artistas. O trabalho de Telfer Stokes demonstra que o formato do livro múltiplo persiste como um meio excitante e acessível nas mãos de um artista comprometido.

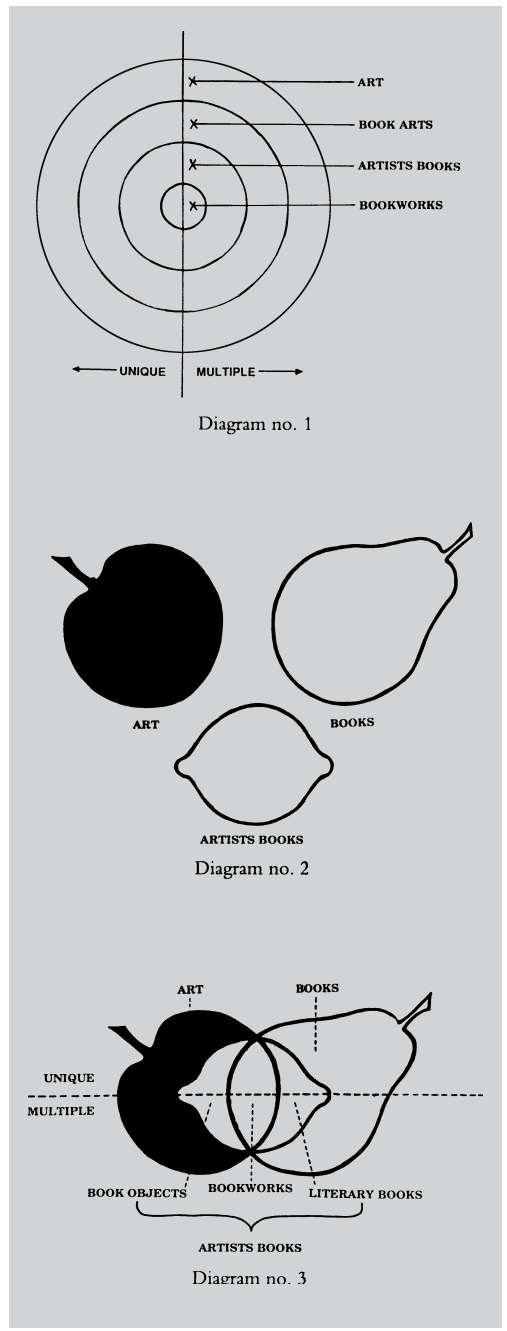

Novos diagramas realizados por Clive Phillpot, para conferência reproduzida em Art Libraries Journal, v. 18, n. $1,1993$.

Phillpot observa que a designação artists' books era usada como tradução do francês tradicional livres d'artistes e livres de luxe, aplicados a edições luxuosas com textos literários preexistentes. A primeira vez em que artists' books foi aplicado para livretos

\footnotetext{
${ }^{7}$ Também Revue de Bibliothèques d'Art, Zeitschrift für Kunstbibliotheken, Revista de Bibliotecas de Arte. O último subtítulo é em espanhol.
} 
concebidos por artistas parece ter sido em 1973 no catálogo da exposição de mesmo nome no Moore College of Art, na Filadélfia. Pode ter sido uma evolução das ideias do crítico italiano Germano Celant para uma mostra em Londres em 1972, Book as Artwork 1960/1972. ${ }^{8}$ Já bookworks teria sido cunhado por Martin Attwood para a exposição Artists' Bookworks, patrocinada pelo British Council para ser exibida na Alemanha em 1975. Phillpot comenta o seu diagrama publicado em 1982 na revista Artforum, depois republicado por Anne Moeglin-Delcroix, na França (1985), e por Artur Brall, na Alemanha (1986). Para tornar mais claro (e sabendo dos problemas particulares - e de crítica de arte - que a definição em outros idiomas pode trazer), ele refaz o diagrama, agora subdividido em três, e com os círculos substituídos por contornos de frutas: os livros representados por uma pêra, a arte por uma maçã (!) e os livros de artista por um limão (!!!). Assim, artists' books podem ser literary books, bookworks ou book objects, independente de serem múltiplos ou únicos.

Para o português, dizemos que os livros de artista, no sentido lato, como um campo das artes visuais, podem ser: livros literários, quando não têm evidentes valores plásticos; livros de artistas propriamente ditos, no sentido estrito, chamados, às vezes, em certos casos, de livros-obras, como tradução literal de bookworks; e livros-objetos, obras escultóricas e matéricas desprovidas de elementos bibliográficos. Deve-se ter em mente que a tradução de bookwork é problemática, uma vez que o inglês permite justaposições e aglutinações com mais liberdade e pronti-

${ }^{8} \mathrm{O}$ texto teve outras republicações, como em Books by artists, organizado por Tim Guest, 1981.
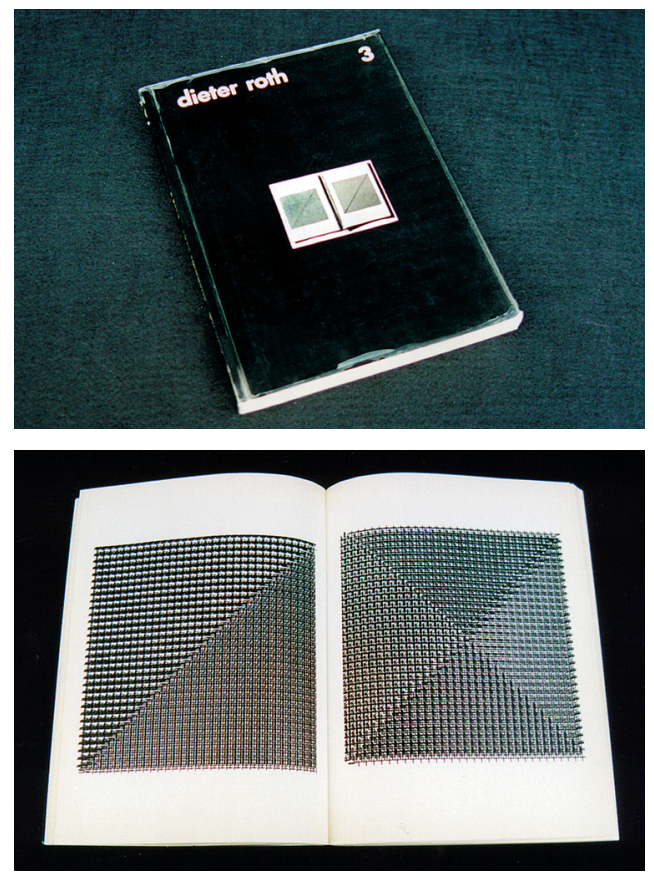

Dieter Roth, Gesammelte werke: band 3: bok $2 a$ und bok 2b, 1973.
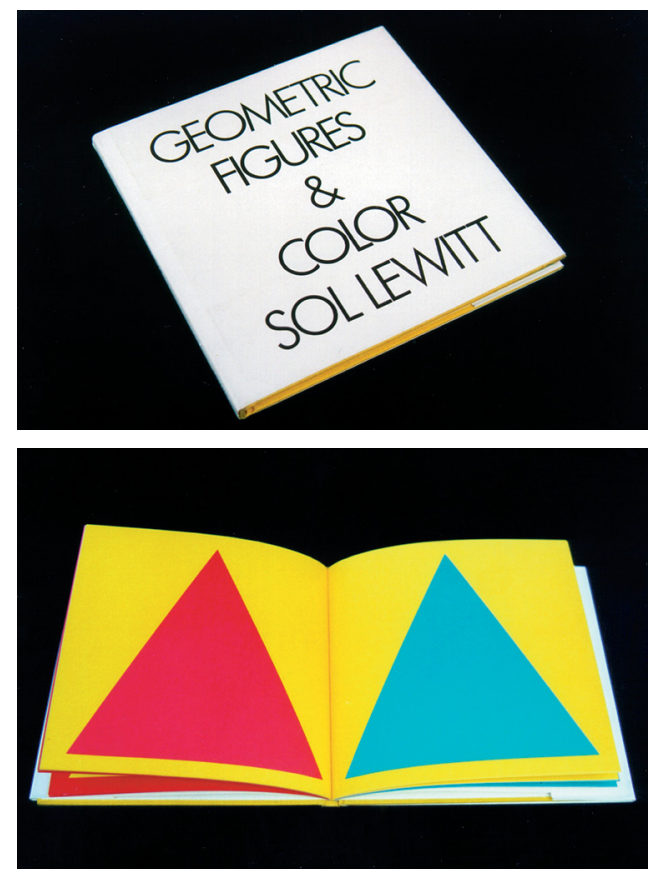

Sol LeWitt, Geometric figures E color, 1979. 
dão. A palavra bookwork é frequentemente traduzida, na nossa fala coloquial, simplesmente como "livro". Mas não pelo seu aspecto literário ou textual, ou verbo-visual, e sim por sua existência física, plasticamente programada e matericamente fundada.

Em 1985, em um artigo para Artists' books: a critical anthology and sourcebook, organizado por Joan Lyons, Phillpot recenseou os vinte nomes para ele mais importantes para

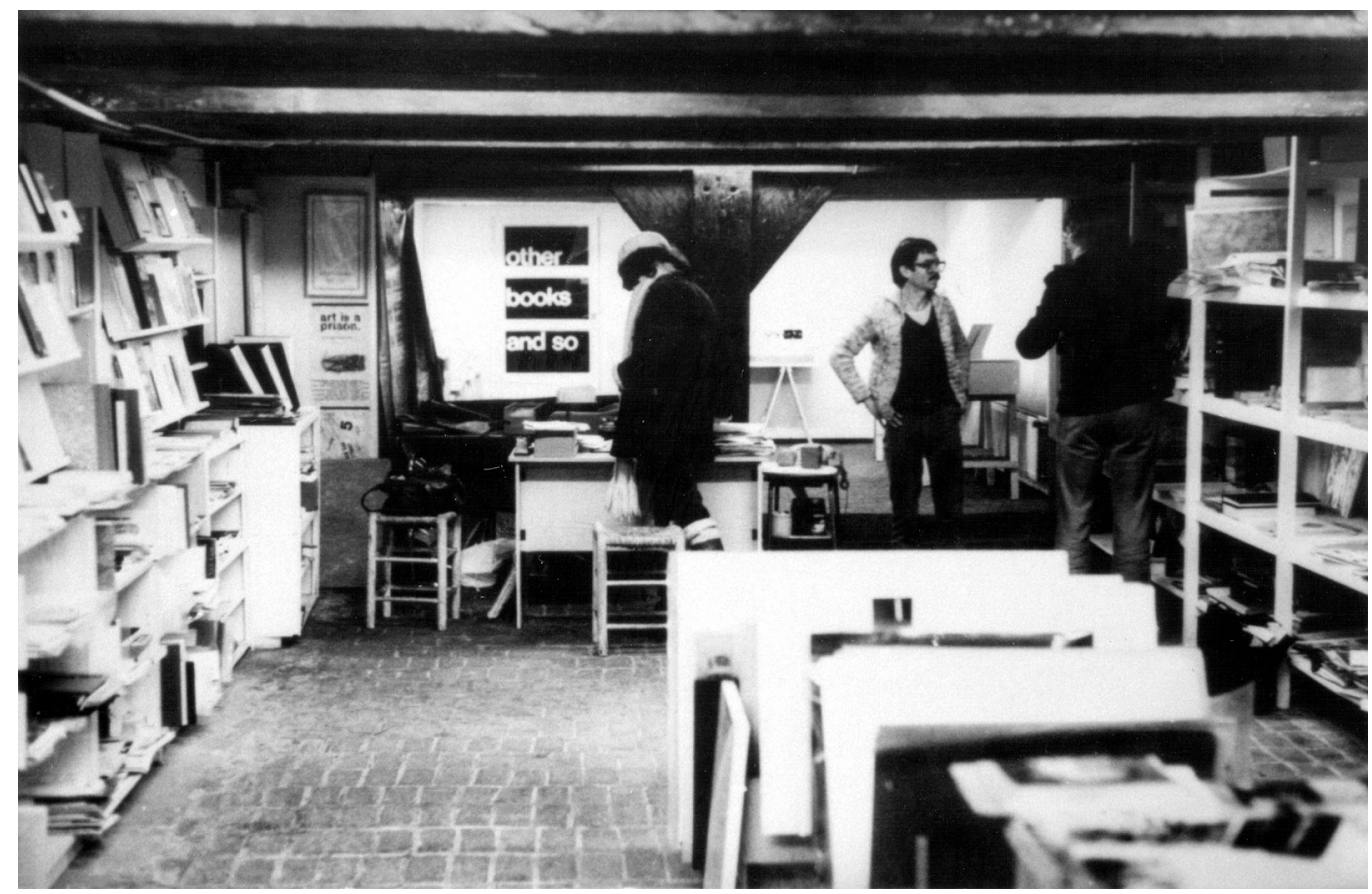

Other Books \& So, Amsterdã, hoje extinta. Ao centro, Ulises Carrión; à esquerda, Flávio Pons; à direita, desconhecido (foto de 1978, cedida pelo Espaço NO - Arquivo).
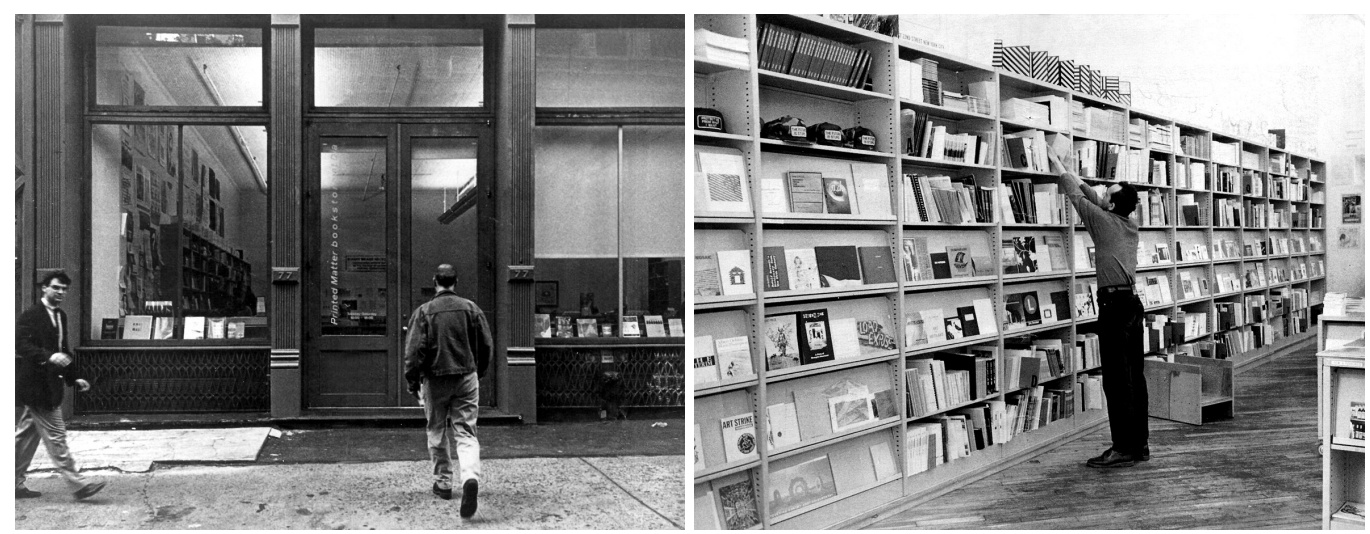

Livraria Printed Matter, Nova York (fotos dos catálogos de 1991 e 1992). 

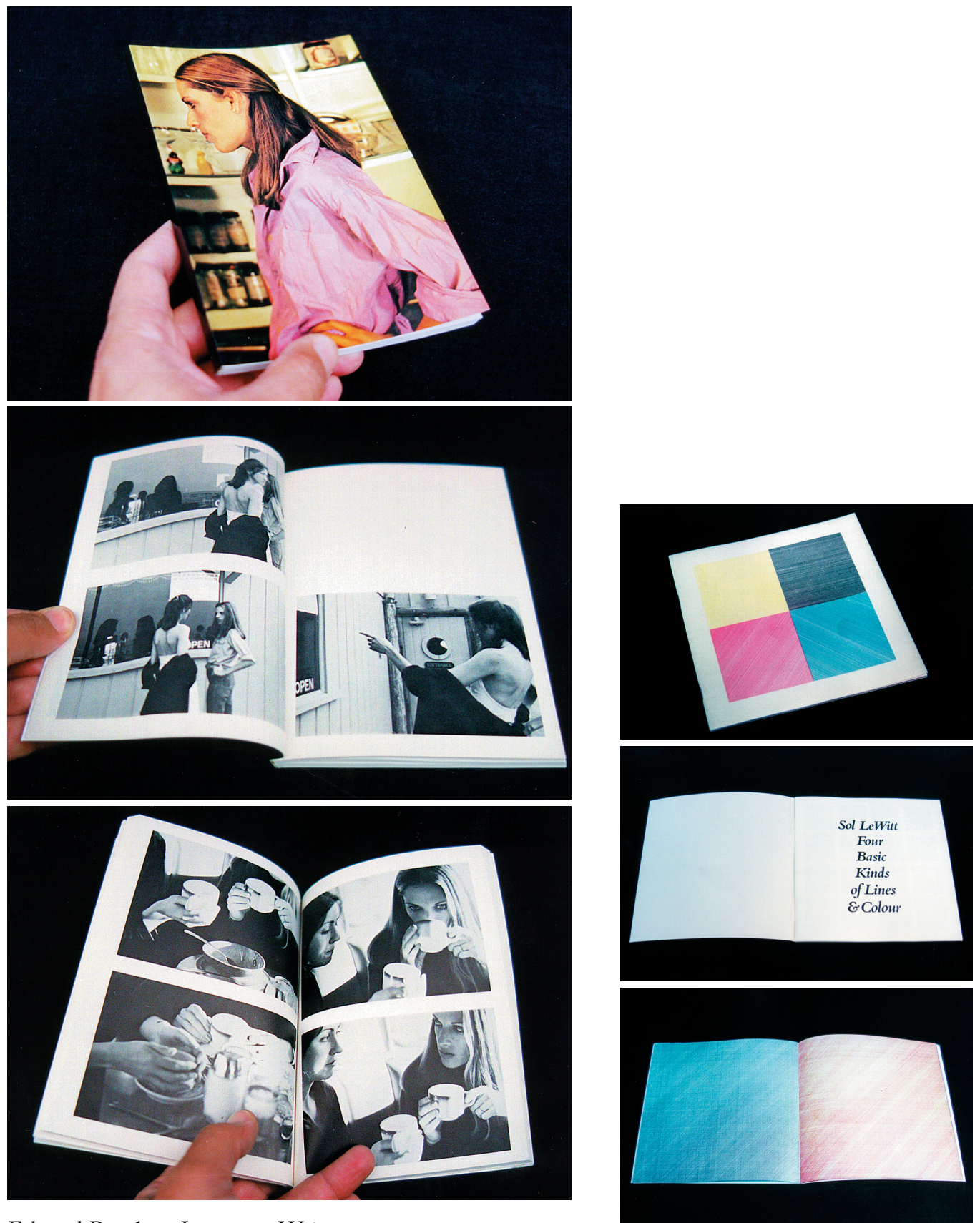

Edward Ruscha e Lawrence Weiner, Hard light, 1978.

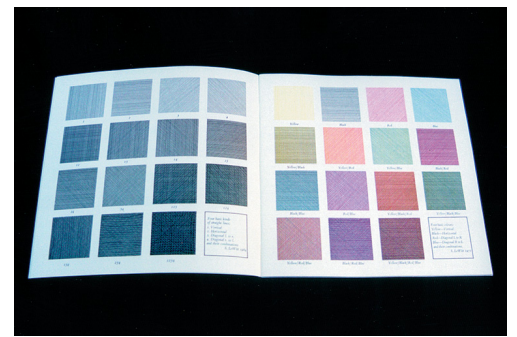



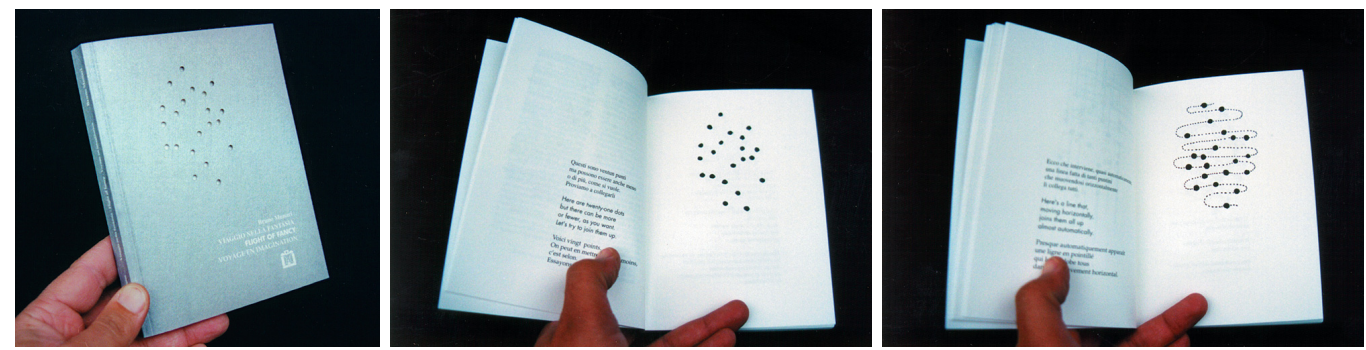

Bruno Munari, Viaggio nella fantasia/ Flight of fancy/ Voyage en imagination, 1998 (segunda edição).

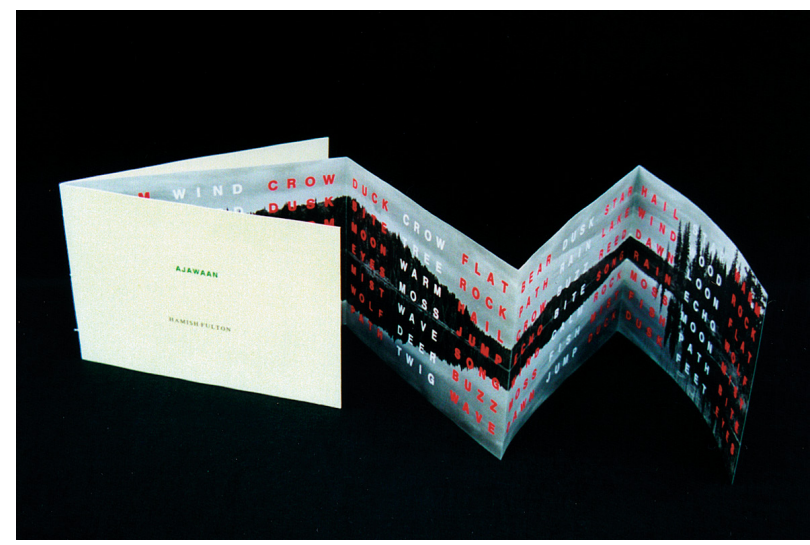

Hamish Fulton, Ajawaan, 1987.

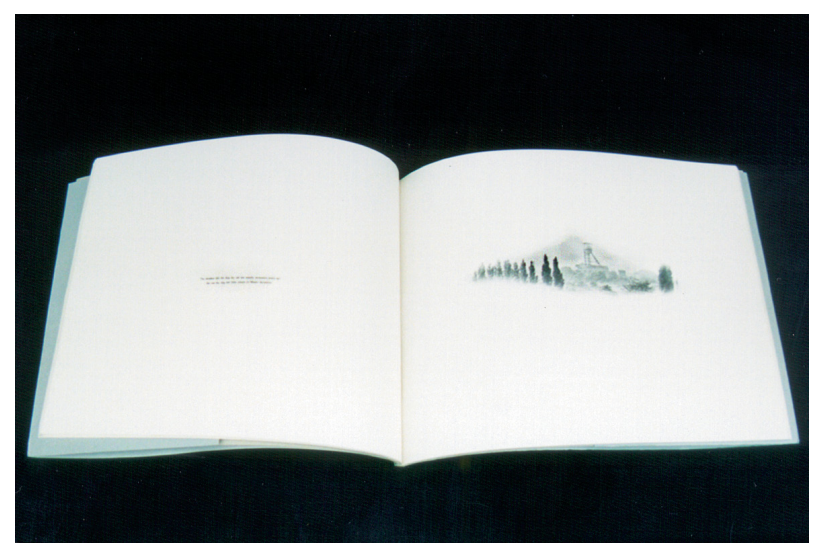

Jochen Gerz, Fuji-Yama-Series, 1981.

Allan Kaprow, Pose, 1970.

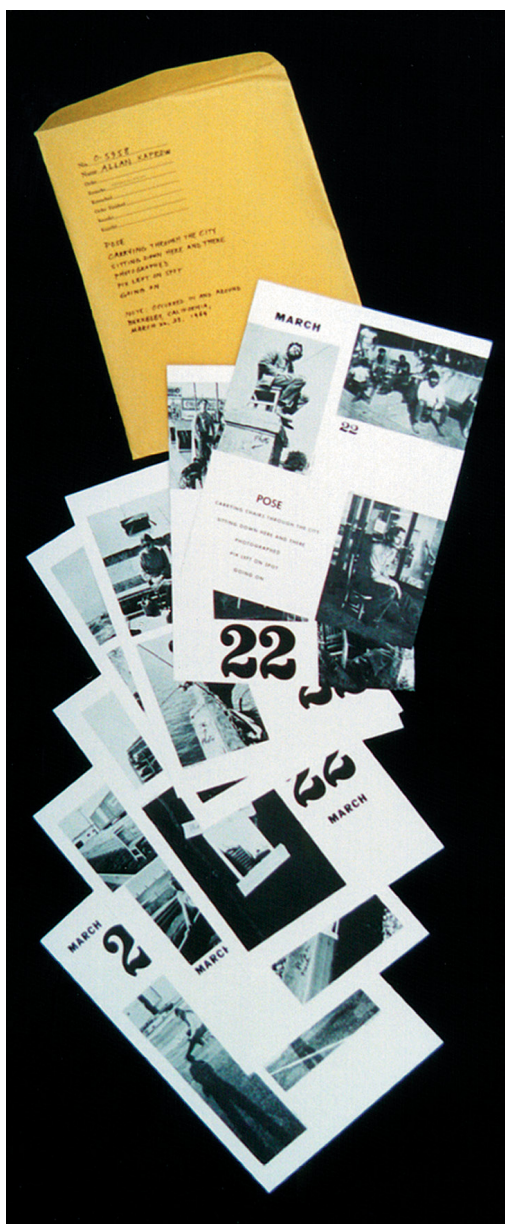


a fundação do moderno livro de artista: Ruscha, Roth, Eduardo Paolozzi, Andy Warhol, Sol LeWitt, Lawrence Weiner, Richard Long, Daniel Buren, John Baldessari, Davi Det Hompson (cognome para David E. Thompson), Telfer Stokes e Kevin Osborn. Para o artigo de 1993 citado, ele acrescenta, inclusive como precursores de Ruscha, o italiano Bruno Munari (com os seus trabalhos da década de 50), o argentino Leandro Katz e o sueco Åke Hodell (principalmente por seus trabalhos de 1961 e 1962, a partir da poesia visual e concreta dependentes do formato livro). Katz e Hodell não são citados nos livros de Castleman, Drucker ou Moeglin-Delcroix.

Com respeito aos livretos de baixo custo, Phillpot registra o que ele vê como "a erosão de ganhos desse movimento, especialmente nos anos 80, como um mercado ampliado para novos tipos de valiosas edições limitadas e antialfabetizados livros únicos”(p.10).A designação artists' book, já imperfeita, se alargaria para abarcar um espectro mais amplo, novamente incluindo edições luxuosas, "a reboque com o crescimento do Reaganismo e do Thatcherismo, e no interesse em um expressionismo em pintura aquecido no microondas. [...] Os sonhos de muitos por uma arte acessível estava rudemente despedaçado”.

Em 1998, em conjunção com a exposição Artist/Author: Contemporary Artists' Books (itinerante pelos Estados Unidos), a Federação Americana de Artes lança um livro organizado por Cornelia Lauf com a participação de Phillpot. Em seu ensaio ele reitera que artist's book é apenas uma convenção, sinônimo de livres d'artiste ou Künstlerbuch (em 1998 o problema ainda continua!). Ele mantém as ressalvas ao livro-objeto, em favor do livro gráfico. Mas coloca mais luz (e mais amplitude) no campo do livro de artista e sua "natureza mestiça". Assim, pertencem a esse campo os seguintes objetos gráficos, entre outros (p.31 e seguintes): revistas que incluem arte para a página (que se comportam como livros de artistas seriais); assemblings (volumes compostos por agrupamentos de páginas feitos por diferentes artistas); antologias (semelhantes aos assemblings, mas com o concurso de um editor); escritos, diários e manifestos; poesia visual e obras com a palavra (desde que componham o volume); partituras e roteiros; documentação; reproduções fac-similadas e cadernos de rascunho; álbuns e inventários; obras gráficas (sem narrativas), às quais convêm o formato livro; histórias em quadrinhos específicas; livros ilustrados; page art (arte de página, iluminuras, interferências gráficas, etc.) e arte postal; arte do livro e bookworks (livros-obra). Essa "taxonomia" é apresentada por Phillpot como um espectro, como o das diferentes cores que no fim compõem a luz branca: "no final do arco-íris, existe um pote de livros-obra" (p.50).

\section{O Brasil e as reticências}

No caso específico do Brasil, a pesquisa tende a ser um pouco entristecedora, pela constatação da mínima (porque quase nula) cobertura do assunto pela bibliografia nacional. Mesmo pelos canais internacionais o acesso ao país é difícil. Alguns artistas 
brasileiros estenderam ou estendem sua atuação até a Europa ou América do Norte, o que de fato poderia ser um caminho para verificar possíveis correntes. Mas através da literatura estrangeira são lembradas apenas a participação paulista no pioneirismo da poesia concreta, em geral, e, em particular, as experiências de Décio Pignatari e Haroldo e Augusto de Campos, com a participação de Julio Plaza. Há que reconhecer que é ponto para as letras. Por outro lado, a obrigação de desvendar cabe ao pesquisador brasileiro, que acaba por omitir essa parte da nossa produção artística.

É claro que tivemos e ainda temos outros expoentes, além desses citados. Mas, grosso modo, houve mais aventura que realização, e as nossas mostras, esporádicas, não possuem a diversidade agressiva das exibições em outros países. Além disso, o fortíssimo vínculo com a palavra (e o respectivo sucesso artístico) formou uma corrente distante da imagem pura ou do trabalho com o volume gráfico. Penso que também outros motivos levaram a isso. Entre eles, causa estranheza o quase nulo conhecimento e aplicação das técnicas de encadernação criativa voltadas às artes plásticas, o que em outros locais tem possibilitado ao artista o exercício de peças únicas, amalgamando conceitos bidimensionais e tridimensionais, além de possibilitar um escape à equivocada obrigatoriedade de uma tiragem significativa.

A falta de informação disponível pode ser verificada tanto na literatura técnica para um grande público (ou ao menos maior que o usual), como na literatura técnica para um público bem mais específico. Como demonstração do primeiro caso, destaco que nas obras mais relevantes e divulgadas sobre a história da arte no Brasil encontrei apenas um texto, da exata extensão de um parágrafo, sobre o livro de artista brasileiro, de Walter Zanini, em História geral da arte no Brasil. É tão curto que pode ser transcrito integralmente.

Uma especificação a se fazer em relação ao trabalho conceitual é a dos livros-de-artista e cadernos-de-artista. Os poetas se anteciparam aos seus colegas das artes plásticas ao encarar o livro como forma de arte. Entre estes, acham-se os pioneiros Lygia Pape, com o Livro da Criação (1958) e Dillon Filho, que em 1960 produziu livros-poemas. Mais tarde também Raimundo Colares credenciou-se com trabalhos nesse sentido.Em 1968, Júlio Pacello editou em São Paulo o Livro-Objeto de Julio Plaza. Nos anos 70 e início desta década, mormente em São Paulo, proliferaram as publicações de artistas, juntamente com as de poetas aparecendo, entre outras, as de Julio Plaza, já citado a esse respeito (por vezes em colaboração com Augusto de Campos), Antônio Dias, Regina Silveira, Gabriel Borba Filho, Carmela Gross, 
Mário Ishikawa, Ivald Granato, Regina Vater, Cláudio Ferlauto, Anna Bella Geiger, Ivens Olinto Machado, Tunga, Vera Barcelos e Flávio Pons, este residente em Amsterdam, entre outros. Uma intimidade estabeleceu-se entre vários deles e os poetas que trabalhavam com a imagem, a exemplo de Edgard Braga (1897), Ronaldo Azeredo (1937), Hermann Villari (1943) e Omar Khouri (1948).

Naturalmente existem outras fontes à disposição (poucas), como os catálogos das mostras Tendências do Livro de Artista no Brasil, São Paulo, 1985, com curadoria de Annateresa Fabris e Cacilda Teixeira da Costa; Livro-Objeto: a Fronteira dos Vazios, Rio de Janeiro, 1994, com curadoria de Marcio Doctors; Ex Libris/Home Page, São Paulo, 1996, com curadoria de Giselle Beiguelman e Sérgio Pizoli e assessoria de Eduardo Braga; e mesmo a nossa Arte Livro Gaúcho: 1950-1983, Porto Alegre, 1983, com projeto e curadoria de Vera Chaves. Outros textos críticos podem ser encontrados no catálogo da mostra itinerante na Itália Brasil: Sinais de Arte - Livros e Vídeos 1950-93. São catálogos que contribuem muito com seus registros e ilustrações, mas que trazem alguns importantes textos teóricos, ainda que pouco significativos quanto à quantidade.

Além desses, existem muitos textos sobre a poesia concreta e visual, incluindo o poema-processo. Mas devem ser analisados com cuidado, já que com frequência se fala em poesia ou poema, e não em livro.

Exposição Ex Libris/Home Page, Paço das Artes, São Paulo, 1996.
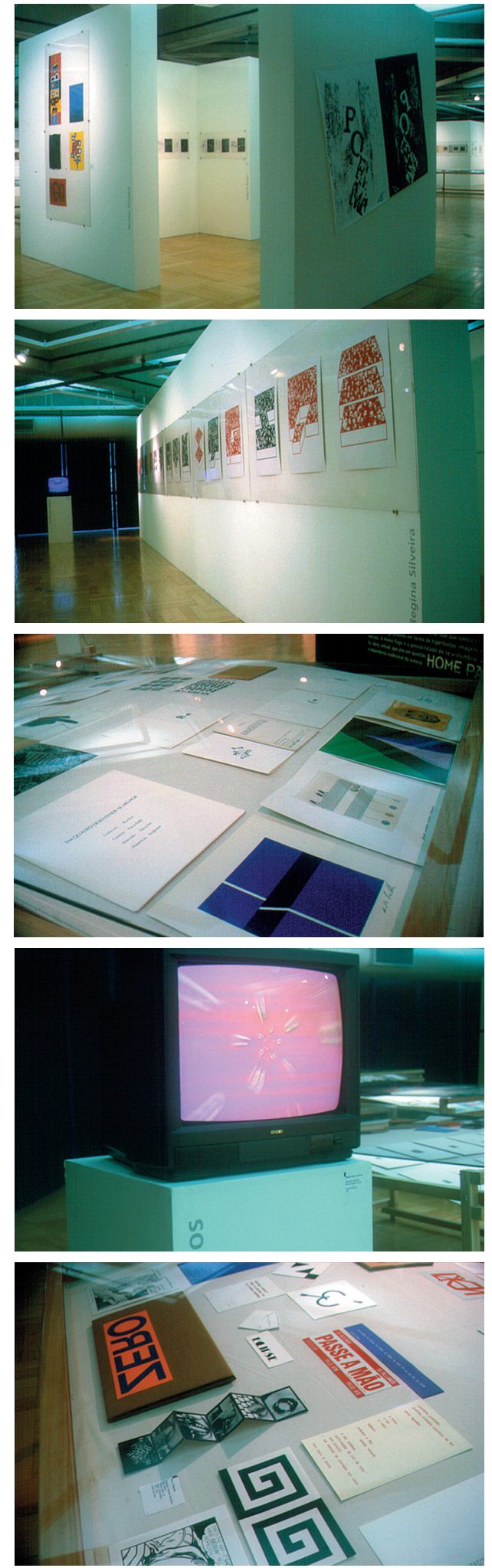


\section{Julio Plaza e a semiótica}

O mais significativo ensaio sobre a estética do livro de artista sob o ponto de vista da semiótica escrito no País foi o artigo de Julio Plaza (nascido na Espanha, mas radicado no Brasil, onde faleceria em 2003), publicado em duas partes em edições sucessivas da revista Arte em São Paulo, em 1982, "O livro como forma de arte". Ele foi precedido por um pequeno texto avulso de mesmo nome, de 1980.

Em "O livro como forma de arte" de 1980, Julio Plaza tenta descrever as possíveis variações de apresentação da edição alternativa, ou "não sistema". Ele privilegia a relação do livro com o poema. A categoria do "livro como arte" teria sido inaugurada com Um lance de dados, de Mallarmé. Muito poucas variações formais são apontadas. $\mathrm{O}$ texto é pequeno e, às vezes, lhe recai o ônus de ser sintético, parecendo não prever os desdobramentos da vanguarda mundial:

Álbuns, Pastas, Port-folios, Edições de Luxo, usando a técnica da fotografia, da gravura ou outras, são simplesmente edições que reúnem trabalhos aglutinados pelo tema comum, e que podem existir perfeitamente dentro e fora dos meios empregados, não participando portanto da problemática espaço-temporal do livro. Estas Edições de Arte se confundem mais com a "arte do editor", tão cara aos bibliófilos, do que com a arte de criar, mais cara aos artistas. (p.3)

Plaza nota que um dos primeiros livros-poemas (que ele apresenta como sinônimo de livro-objeto e livro-obra) foi $A$ ave, de Wlademir Dias Pino (mais tarde Dias-Pino), 1954. De fato, essa obra parece estar entre as precursoras mundiais dos livros visuais.

Em outro pequeno texto do mesmo ano, Samizdat como comunicação alternativa, ele complementa o trabalho anterior com exemplos mais ágeis. Samizdat é russo, referindo-se a "toda a produção veiculada através da mídia precária e ideologicamente
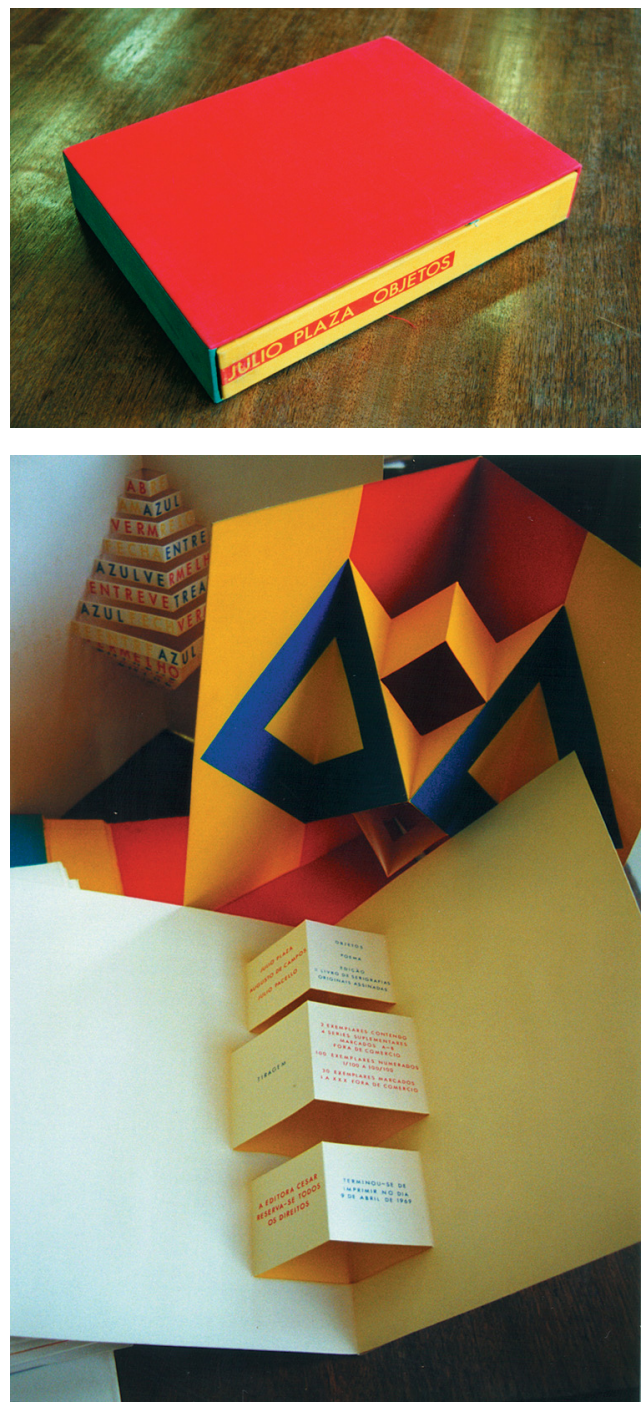

Julio Plaza, Objetos, 1969. 
antagônica ao poder soviético". Aqui a palavra é utilizada em sentido figurado. Destaca a atuação internacional do grupo Fluxus e do grupo Noigandres. Mas no Brasil a produção individualista seria tão marginal quanto a produção "sistema". Plaza faz a defesa dos artistas independentes.

“O livro como forma de arte", de 1982,é fruto direto do desenvolvimento dos textos anteriores. É um dos principais instrumentos de referência publicado no Brasil, o que não o impede de gerar algumas dúvidas. Dentre as razões cito três.

1. Plaza é rigoroso na classificação tipológica. Mas mesmo sendo tão afirmativo, ele fica indefinido pela grafia de livro de artista, palavra que poderia ter sido redigida com hifens, como o foi no catálogo da XVI Bienal de São Paulo. Isso poderia ter sido comentado, já que é importante para o estabelecimento apropriado de definições. Qualquer livro de artista é um livro, mas nem todo livro de artista o é. Podemos dizer a mesa redonda, e estamos falando da mesa (que é redonda); ou podemos dizer a mesa-redonda, e estamos falando de um tipo específico de atividade. A unidade semântica é dada, em português, principalmente pelo uso do hífen, como o apóstrofo e a aglutinação no inglês, por exemplo (artist's book e bookwork). Do mesmo modo, o objeto livro (o objeto de uso cotidiano ao qual denominamos como livro) e o objeto-livro (como uma proposta de especificação conceitual do objeto artís-

${ }^{9} \mathrm{O}$ assunto pode ser verificado em gramáticas e possui regras mais ou menos claras desde 1945. Por exemplo, citemos o Novo manual de português, de Celso Pedro Luft e outros, São Paulo: Globo, 1995.Páginas 197 e 198. (Primeira edição de 1971.)
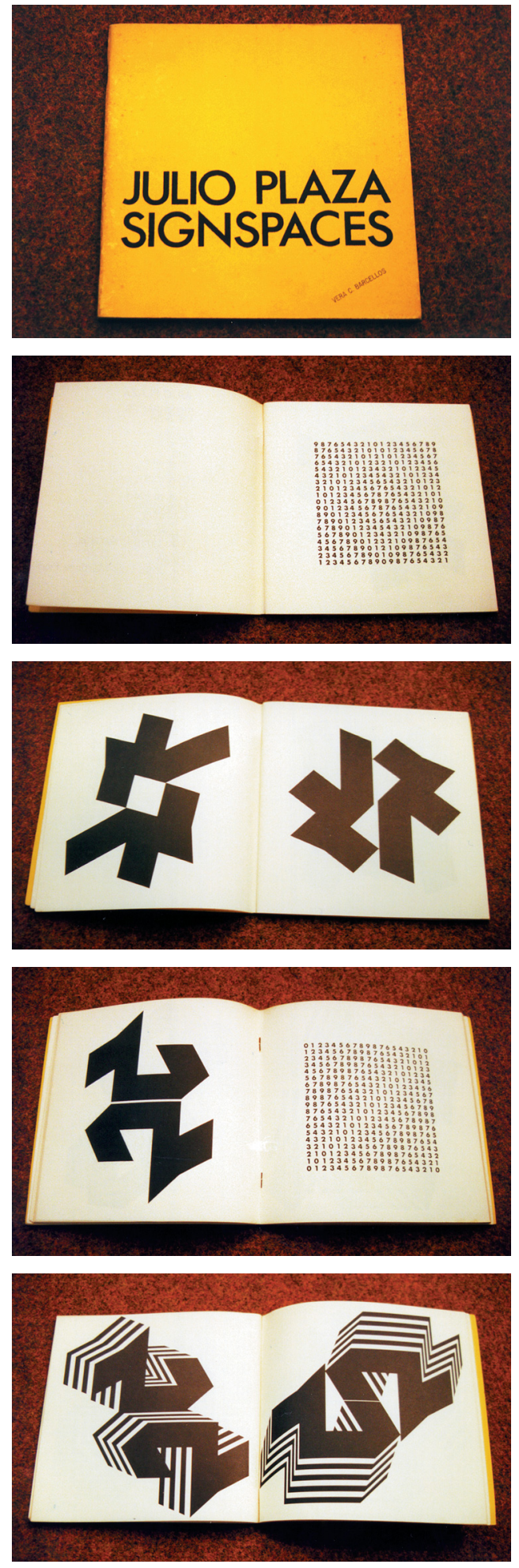

Julio Plaza, Signspaces, 1970 (1967-1969). 
tico). Não importa se estando correta ou incorreta sua solução, o problema poderia implicar fortemente todo o modelo que se pretendia construir, porque influiria no conceito. O "livro-de-artista" e o "livro de artista" incluirão ou não o "não-livro". Esse problema de grafia persistiu no Brasil. Como já foi observado, em catálogos como Sinais de arte... há grafias com e sem hífen, dependendo do autor.

2. Os primeiros parágrafos da primeira parte usam de transcrições de um texto muito divulgado de Ulises Carrión, $A$ nova arte de fazer livros. Carrión (1941-1989) era mexicano, estudou na França, mas radicou-se na Holanda, onde abriu a primeira livraria de livros de artista da Europa, a Other Books \& So, em 1975, dividindo sua administração com Aart van Barneveld. Influenciou muitos artistas no mundo todo, inclusive os ligados ao Espaço NO, em Porto Alegre. Parece ter sido uma das mais valiosas contribuições ao pensamento de Plaza no que diz respeito a natureza sequencial do livro. O trabalho de Carrión está citado da bibliografia do artigo de Plaza, mas já no texto fica bem marcada a sua importância. Vejamos um trecho de Plaza.
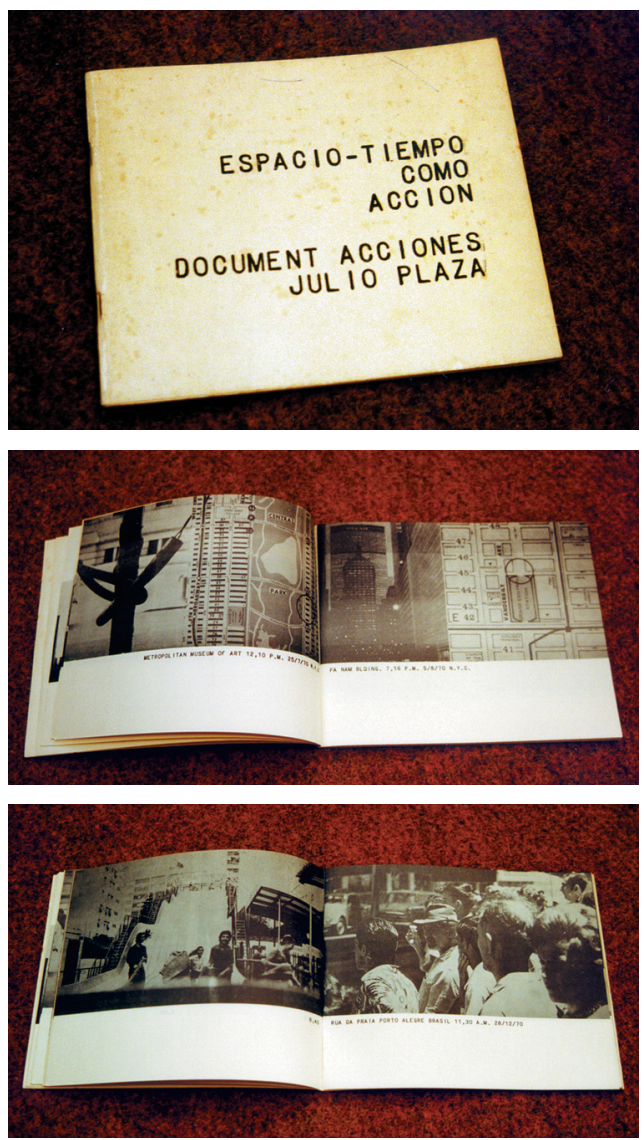

Julio Plaza, Espacio-tiempo como accion, 1971 (leiaute de Vera Roitman).

[...] Livro é uma sequência de espaços (planos) em que cada um é percebido como um momento diferente. O livro é, portanto, uma sequência de momentos.

O livro é signo, é linguagem espaço-temporal.

O texto verbal contido num livro ignora o fato que o livro é uma estrutura autônoma espaço-temporal em sequência. Uma série de textos, poemas ou outros signos, distribuídos através do livro, seguindo uma ordem particular e sequencial, revela a natureza do livro como estrutura espaço-temporal. Esta disposição revela a sequência, mas não a incorpora, não a assimila. [...]

Comparemos com Carrión.

Um livro é uma sequência de espaços.

Cada um desses espaços é percebido num momento diferente - um livro é também uma sequência de momentos. [...] 
Um texto literário (prosa) contido num livro ignora o fato de que o livro é uma sequência espaço-tempo autônoma.

Uma série de textos mais ou menos pequenos (poemas de outro) distribuídos por todo o livro, seguindo uma disposição específica, revela a natureza sequencial do livro.

Isto o revela, talvez o utilize; porém não o incorpora ou assimila. [...] [...]

O livro é uma sequência espaço-tempo

Naturalmente, a liberdade na apresentação de seu trabalho é uma manifestação de sua agilidade criativa, que não diminui em nada seu valor. $\mathrm{O}$ problema é que isso dificulta as transcrições necessárias numa dissertação subsequente, num processo que poderia se multiplicar em cadeia. Ou seja: se eu preciso citar Plaza, como fazer para separá-lo de Carrión?

3. A segunda parte é sobre o que Plaza chama de livro anartístico, um neologismo desajeitado. Em etimologia (ver os dicionários citados) o prefixo $a(a n)$ indica uma negação, privação, oposição ou um movimento contrário ao conceito do radical que o segue. Não me parece um substantivo adequado ao que ele está por demonstrar. Talvez seja uma reincidência da formação de palavras com forte espírito poético de que tanto gostamos nas artes visuais, mas que às vezes induzem a equívocos. Talvez no entendimento $\mathrm{da}$ palavra artístico é que esteja o problema. O fato é que não está claro. E num estudo desse tipo é preciso clareza. Ou é artístico, ou não é, ou quase é. Nesse momento do texto algo não funciona.

Plaza demonstra que o livro de artista se apresenta em três tipos de montagem. Reconhece que o livro-objeto apresenta in-
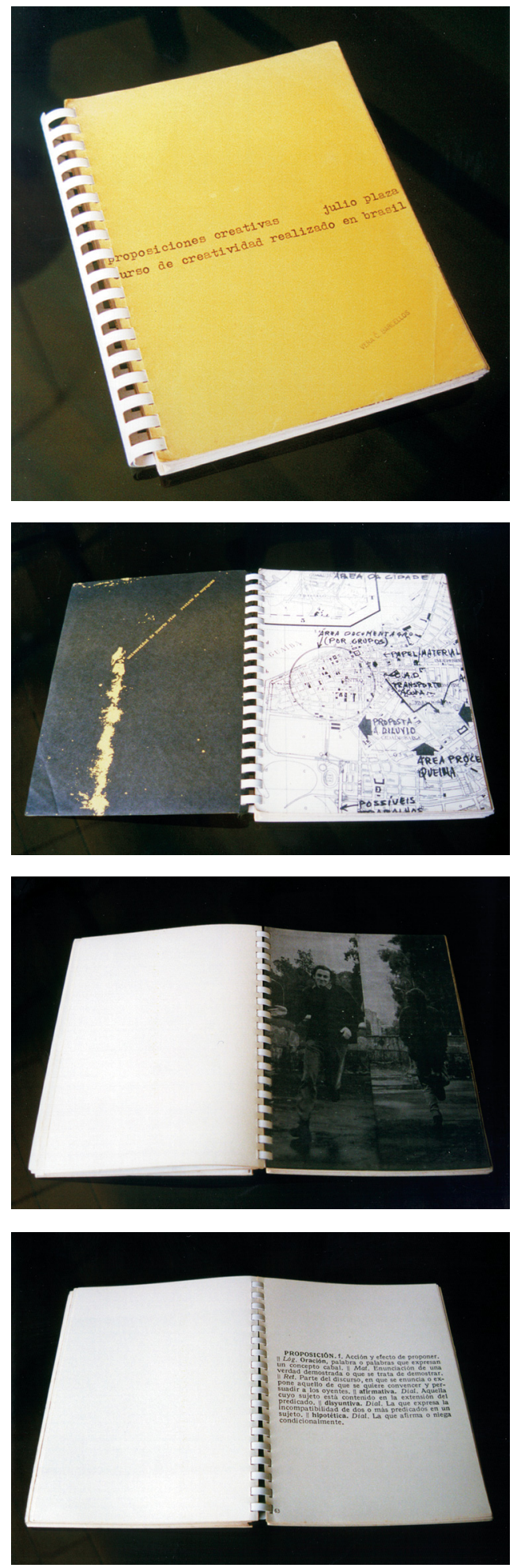

Julio Plaza, Proposiciones creativas, 1972. 


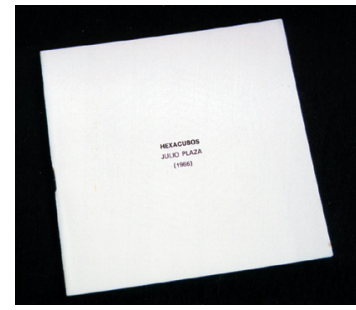

Julio Plaza, Hexacubos, 1966.

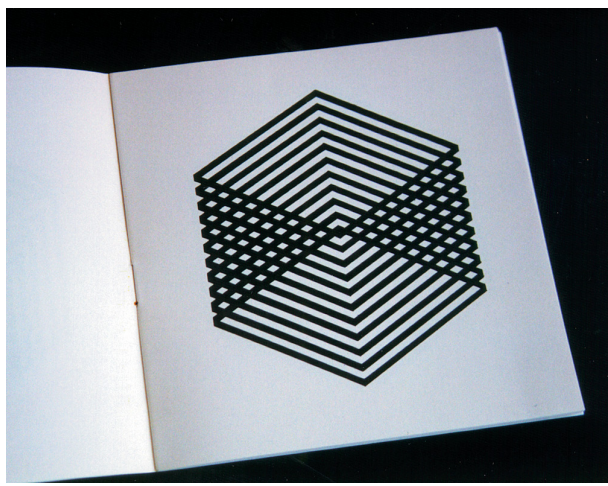

Augusto de Campos e Julio Plaza, Poemóbiles, 1974.
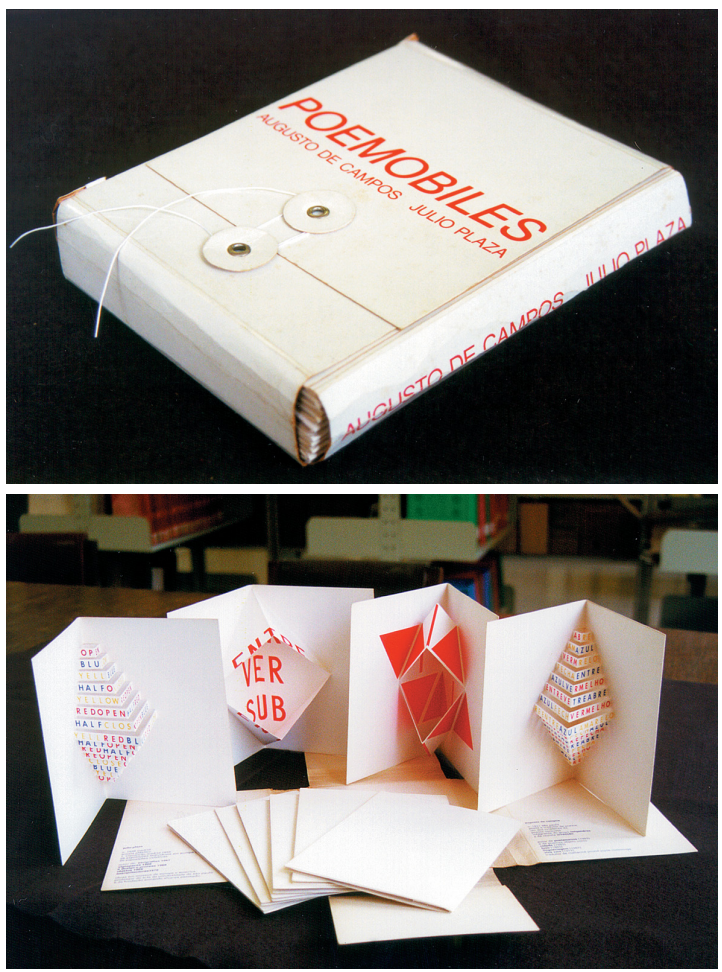

Julio Plaza,

I-Ching,

1977-1978.
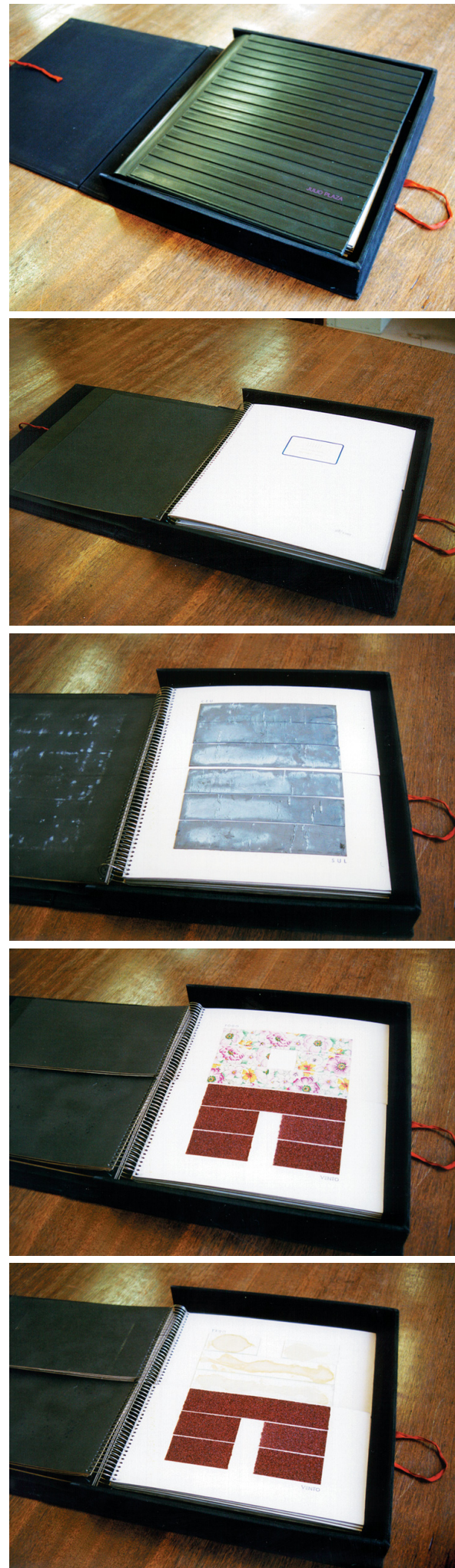
terpenetração entre a informação e o suporte, constituindo a "montagem sintática". Isso faz dele "intraduzível para outro sistema, ou meio", o que o individualiza. É diferente, portanto, da "montagem semântica", por contiguidade, como nos livros ilustrados. A "montagem pragmática" é a formada por bricolagem de elementos de outras estruturas estéticas, como nos livros formados por documentos, nas publicações coletivas e nos museus pessoais.

Plaza constrói um quadro (diagrama) onde pretende reunir “todas" as categorias de livros encontrados em dois grandes grupos. O primeiro grupo é o sintético-ideogrâmico, formado pelo livro ilustrado, o poema-livro e o livro-poema (ou livro-objeto, ou livro-obra). O segundo grupo é o analítico-discursivo (ou livro anartístico), formado pelo livro conceitual, o livro-documento e o livro intermedia (sic). Fora dos livros de artista está o antilivro, "como uma categoria onde a ideia do livro se esvai e extrapola para outra linguagem". Plaza não considera o antilivro como livro de artista, embora o considere obra de arte.

O terceiro capítulo deste trabalho evoluirá a partir das afirmações de Plaza de que "o livro é um sintagma sobre o qual se projeta o paradigma página", e de que "o antilivro, antes de mais nada, é uma perversão sobre o livro" (as páginas não são numeradas).

É preciso reconhecer o mérito pioneiro de Plaza, extraordinário pelo que fez e pelo que pensou. Pelo sim e pelo não, ele colocou a nossa disposição uma ampla gama de ferramentas. Além disso, seu trabalho como curador da seção de arte postal na Bienal de São Paulo de 1981 foi de inestimável importância. ${ }^{10}$

\section{Catarina Knychala: o livro de arte}

O maior trabalho em extensão a pesquisar o cruzamento entre arte e livro (mas mais simples e claro no desenvolvimento de sua problemática), é a dissertação de mestrado para a Universidade de Brasília de Catarina Knychala, intitulada O livro de arte brasileiro,

\footnotetext{
${ }^{10}$ Leonor Amarante, em As Bienais de São Paulo: 1951 a 1987 (São Paulo: Projeto, 1989, p.289 e 290), faz severas críticas à curadoria de Plaza. Essas críticas parecem não ser adequadas já que a própria autora se confunde quanto à importância na XVI Bienal, de 1981, da arte-postal e do livro de artista, embora reconheça que "o Núcleo I englobou, de fato, o que havia de mais inquietante e atual em todo o conjunto exposto na $16^{\mathrm{a}}$ Bienal". Entretanto, destina uma página e meia para a videoarte, sem dar destaque para os livros de artista. A crítica a Plaza fica clara nos comentários feitos em seguida: "O impasse dialético quantidade-qualidade não foi superado na sala de Arte Postal, sob curadoria de Julio Plaza. Com pouco rigor seletivo, juntou nada menos que 220 artistas. O público saiu perdendo. Confuso em meio à imensa profusão de trabalhos, deixou de apreciar com tranquilidade, entre outras, as propostas dos brasileiros Bené Fonteles, Rafael França, Hudnilson Jr., Alex Flemming e Luís Guardia Neto, um dos pioneiros da arte postal no país." Bem antes, em 1981 mesmo, Aracy Amaral já tinha feito esses comentários, acrescidos de considerações críticas. Sobre isso, ver Amaral, 1982, p.395.
} 
publicada em 1983, o volume 1, e em 1984, o volume 2. Em nenhum momento ela fala em livro de artista. $\mathrm{O}$ seu assunto é assim apresentado na "Introdução" (p.10-11):

Será considerado livro de arte aquele que se apresenta como um objeto com valores estéticos tais como boa qualidade e beleza do papel, dos caracteres tipográficos e da encadernação, arquitetura e diagramação harmoniosas e não necessariamente ilustrado; mas, se contiver ilustração, serão consideradas não só as ilustrações feitas com processos manuais, como a xilogravura, a gravura em metal, a litografia e a serigrafia, como também fotografias artísticas e reproduções por processos fotomecânicos.

Considerar-se-ão, no levantamento dos livros de arte, tanto o livro produzido propositalmente como obra de arte, com técnicas e materiais que o distingue dos demais livros publicados em sua época, com tiragem limitada, e destinado a um pequeno número de pessoas, como também o livro produzido natural e espontaneamente como obra de arte, com técnicas e materiais próprios de seu tempo.
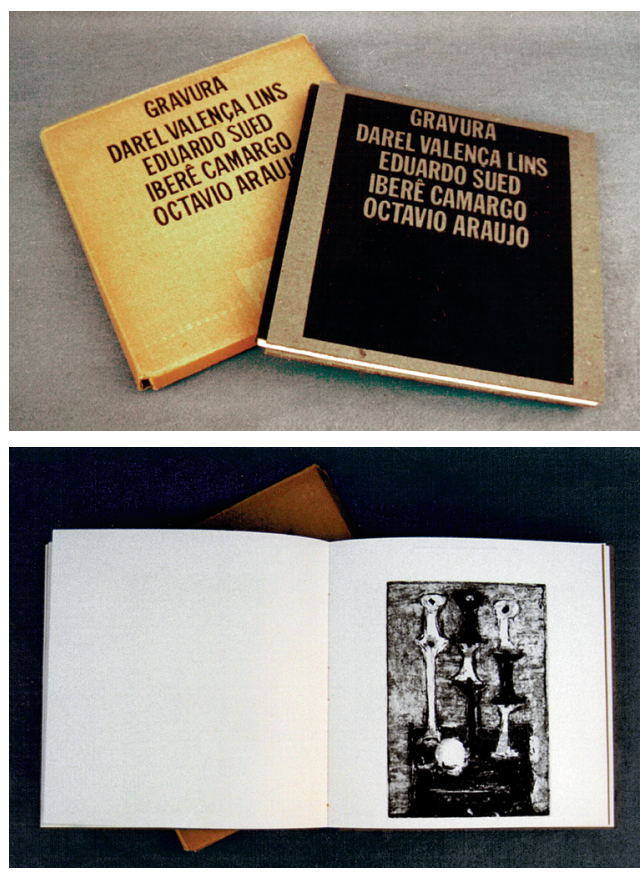

Gravura:

Darel Valença Lins,

Eduardo Sued,

Iberê Camargo,

Octavio Araujo, 1973.

Embaixo: trabalho de Iberê Camargo.

O que o estudo enfoca é apenas o livro tradicional, os estojos e o formato álbum, não se aventurando nas vanguardas e não correndo riscos. Demonstra serenidade e propõe um método de descrição do livro de arte com fins bibliológicos e iconográficos. Mas graças a abrangência da pesquisa, pode-se encontrar informações importantes sobre as experiências editoriais dos anos 50 a 70 no centro do País e no Nordeste, que, afinal, estiveram na retaguarda das experiências compósitas entre poesia e arte: editoras $\mathrm{O}$ Gráfico Amador, Alumbramento, Invenção, Massao Ohno, etc. No segundo volume, todos os cinquenta livros estudados são peças de colaboração entre artistas e escritores. Como exemplo, no caso de Iberê Camargo (para citarmos um nome gaúcho) o trabalho examinado é $O$ rebelde, texto de Inglês de Sousa, editado no Rio de Janeiro em 1952 pela Sociedade dos Cem Bibliófilos do Brasil, com tiragem de 119 exemplares, formado por um estojo com 121 páginas, incluídas 29 águas-tintas, e matrizes destruídas após a impressão. Em casos como esse, em que o mercado de arte cria valor de mercadoria para a obra antecipadamente, até o moderno é engolido e torna-se clássico. 


\section{Annateresa Fabris e Cacilda Teixeira da Costa}

Os melhores resumos históricos do desenvolvimento do livro de artista no Brasil foram realizados por Annateresa Fabris e Cacilda Teixeira da Costa nos anos 80. Esteve sob sua curadoria a exposição Tendências do Livro de Artista no Brasil, em 1985, em São Paulo. O texto para o catálogo da mostra inicia tocando diretamente no problema.

Se internacionalmente os livros de artista constituem uma das áreas mais desconhecidas e "fechadas" das artes plásticas, no Brasil são quase inacessíveis. Embora numerosos, não são vistos regularmente; sua publicação é rara e a apreciação dificilmente ultrapassa um reduzido círculo de iniciados, artistas, poetas e bibliófilos.

O parágrafo anterior é o primeiro da "Apresentação". Agora estamos em 1999. Tudo demonstra que essa realidade mudou minimamente.

O enfoque do texto principal é o de uma resenha que parte dos fundamentos de uma realidade mundial, transferindo sua atenção para um abrangente levantamento da produção brasileira até então. A postura, como foi dito, é historiográfica e clara. Pode-se discordar, apenas, do uso do termo "livro-poema", como em Plaza, que aproxima excessivamente da literatura uma peça de arte que é visualmente programada.

Em 1988, Annateresa Fabris publicou no jornal $O$ Estado de S. Paulo o artigo "O livro de artista: da ilustração ao objeto". Parte do princípio de que "a multiplicação
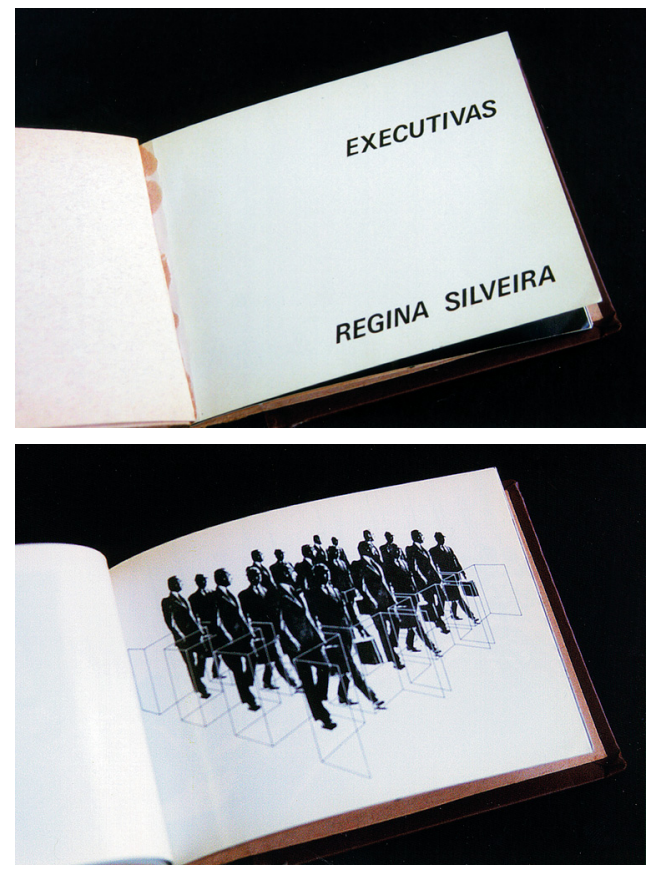

Regina Silveira, Executivas, 1977

(a encadernação não é original).
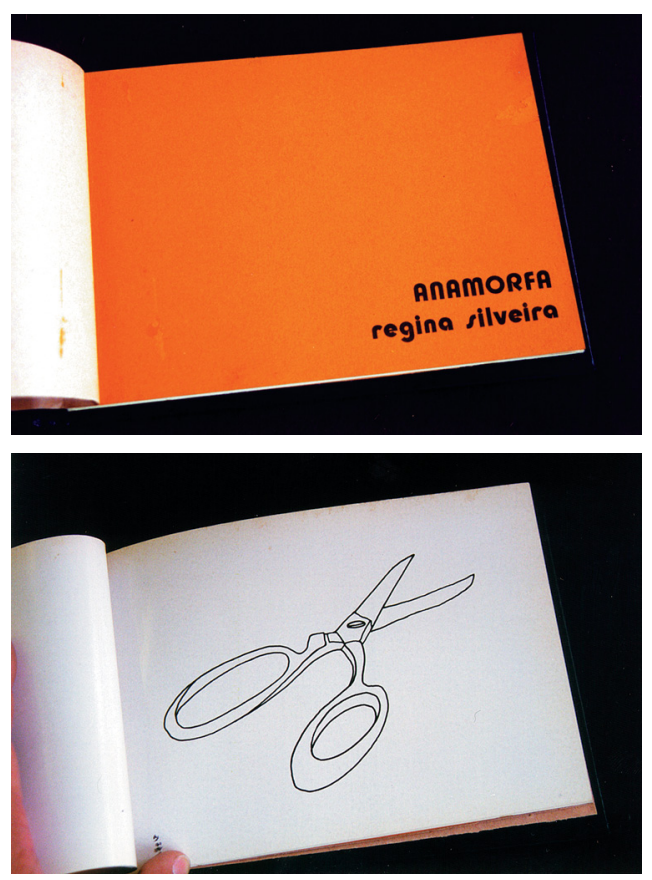

Regina Silveira, Anamorfa, 1979 (a encadernação não é original). 
de sua prática na nossa década [de 80] e a reflexão suscitada por ele parecem constituir claros indícios de que esse veículo alternativo não esgota sua significação no processo minimalista-conceitual, não podendo, portanto, ser pensado só a partir dele”. Fabris localiza o primórdio do livro de artista na união entre a arte e a literatura em William Blake, e seu ponto de mutação em John Cage (Silence, 1961), com a transformação numa estrutura intelectual "que revela a pesquisa inerente às operações artísticas, que enfatiza o processo de leitura em detrimento da percepção, o conceito em detrimento da contemplação".

Como ponto de inovação nesse campo no Brasil, Fabris também relembra a importância de $A$ ave (1956), de Wlademir Dias Pino, fundamental para a renovação neoconcreta que viria a seguir. Essa movimentação geraria desdobramentos que fariam da década de 70 a mais multifacetada no Brasil.

A expressão política (Santiago/Brusky, Plaza, Ishikawa, Artur Matuck), a reflexão sobre a arte (Anna Bella Geiger, Maria Luiza Saddi, Rute Gusmão, Regina Silveira, Essila Paraíso, Carmela Gross, Antonio Dias, Regina Vater), o registro de performances (Gretta, Granato), a visão feminista (Anésia Pacheco Chaves, Mary Dritschel), as pesquisas semântico-semiológicas (Mira Schendel, Plaza, Regina Silveira, Gerty Saruê, Lizárraga), as experiências com xerox (Aloísio Magalhães, Krasniansky, Hudnilson Jr., Brancatelli, Mário Ramiro, Rafael França, Christello), as sequências narrativas (Diana Domingues, Vallauri, Léon Ferrari, Fervenza, Otacílio Camilo), as pesquisas de poesia visual (Edgar Braga, Villari Hermann, Walter Silveira, Bonvicino, Lenora de Barros) vêm enriquecer um panorama que, no fim da década de 60 , fora caracterizado pelos
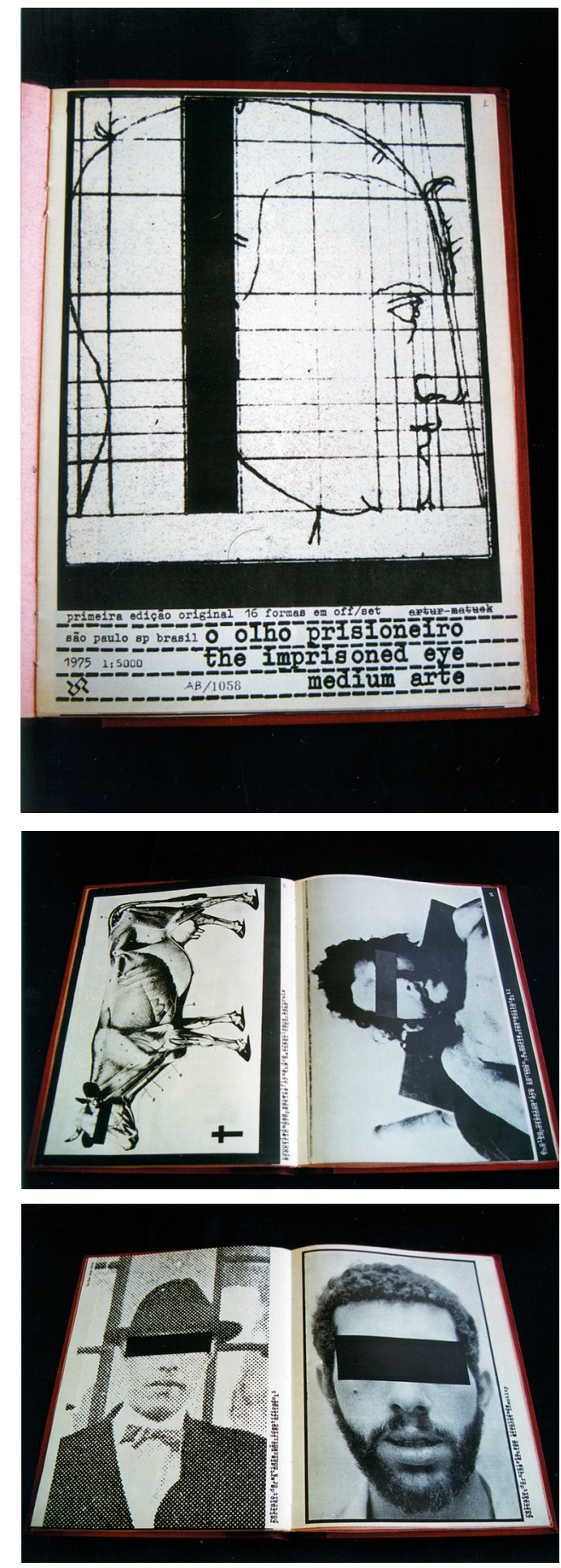

Artur Matuck, O olho prisioneiro, 1975 (a encadernação não é original). 
registros expressivo-reflexivos de Barrio, próximos da poética italiana da arte povera.

A tendência atual do objeto sensual, que já acontecia nos anos 80 , é esboçada rapidamente, sendo citados Antonio Violleta, Luciano Bartolini, Judith Levy e Eugênia Balcells.

A publicação desse artigo em um jornal de grande tiragem, e que já distribuía uma parcela de sua edição para outros estados, se constitui num momento especial de aproximação entre a arte marginal e o público leitor de jornais. A lamentar, apenas, as ilustrações, que parecem ou são reproduções de imagens bidimensionais. A imagem, aqui, é obliteradora: não é possível ver nenhum livro. O que, por sinal, viria a ser o mesmo problema do livro de Zanini já citado.

Em 1996, para a exposição Portinari Leitor, no Museu de Arte Moderna de São Paulo, com curadoria e textos de Costa e Fabris, as autoras comentam ilustrações (ou iluminações) realizadas por Cândido Portinari para obras de Machado de Assis, Miguel de Cervantes e Hans Staden. No texto de Costa, O pintor e seus livros, é utilizado o termo "livro de pintor" para designar as obras de colaboração do final do século 19 e começo do 20. Mas ao traduzir como artist's book na versão para o inglês, está sendo afirmada uma postura conservadora, já que existe suficiente material publicado sobre o assunto. Livro de pintor, quando dito em inglês, preserva a grafia do francês livre de peintre. Ingleses e norte-americanos procuram ter o mesmo cuidado com o uso de artist's book, objetivando demarcar uma vanguarda e uma contemporaneidade. E, como já vimos, essa demarcação chega a provocar o distancia-
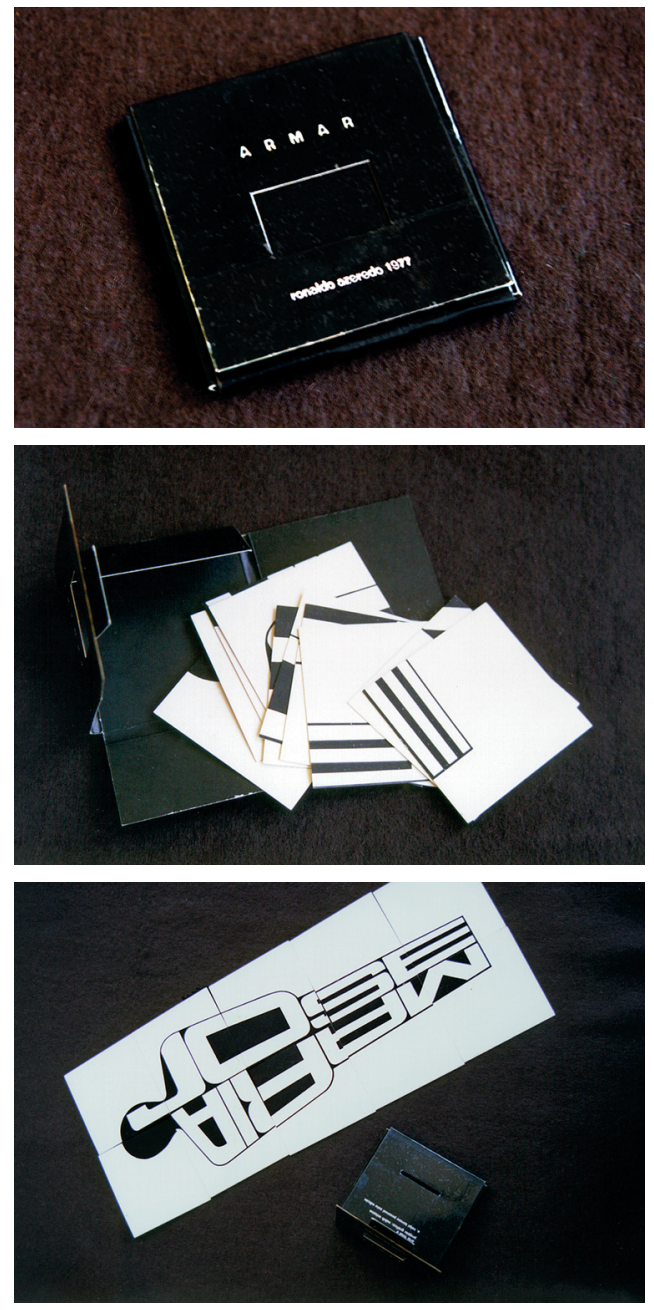

Ronaldo Azeredo, Armar, 77.

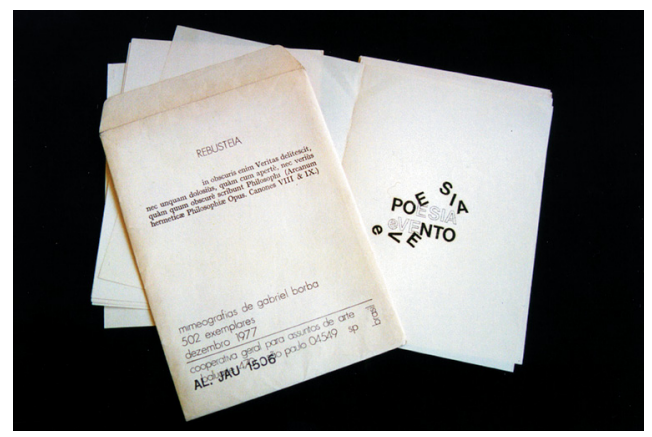

Gabriel Borba, Rebusteia, 1977. 


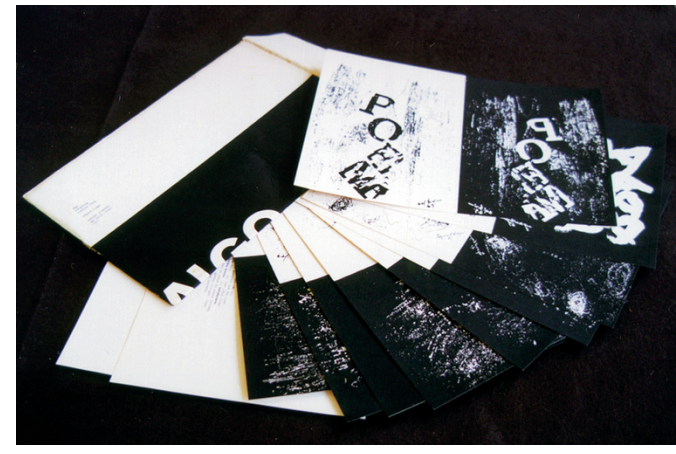

Edgard Braga, Algo, 1971.

mento, para um lado, do livro-ilustrado, e, para outro, do livro-objeto.

É curioso. Existe uma história do livro de artista ainda sendo escrita, tanto brasileiro, como mundial. Mas essa história não se define quanto ao seu começo, porque não se define quanto ao conceito do que o seu objeto é exatamente. Enquanto isso, trabalhos mais ou menos escultóricos, emocionais, entram na festa sem serem convidados e exigem atenção. Os furões negam as normas da lista de convidados, que deveriam ser cerebrais, e acabam por se colocar marginais aos marginais. Parece que já chegaram com a sua própria bebida,já parcialmente digerida. Os pesquisadores se travestem de garçons. São finamente orientados, mas, pela própria característica do evento, servindo em todas as direções. Motivo pelo qual também o estudo das pesquisas envolvidas tem suas páginas de paixão.
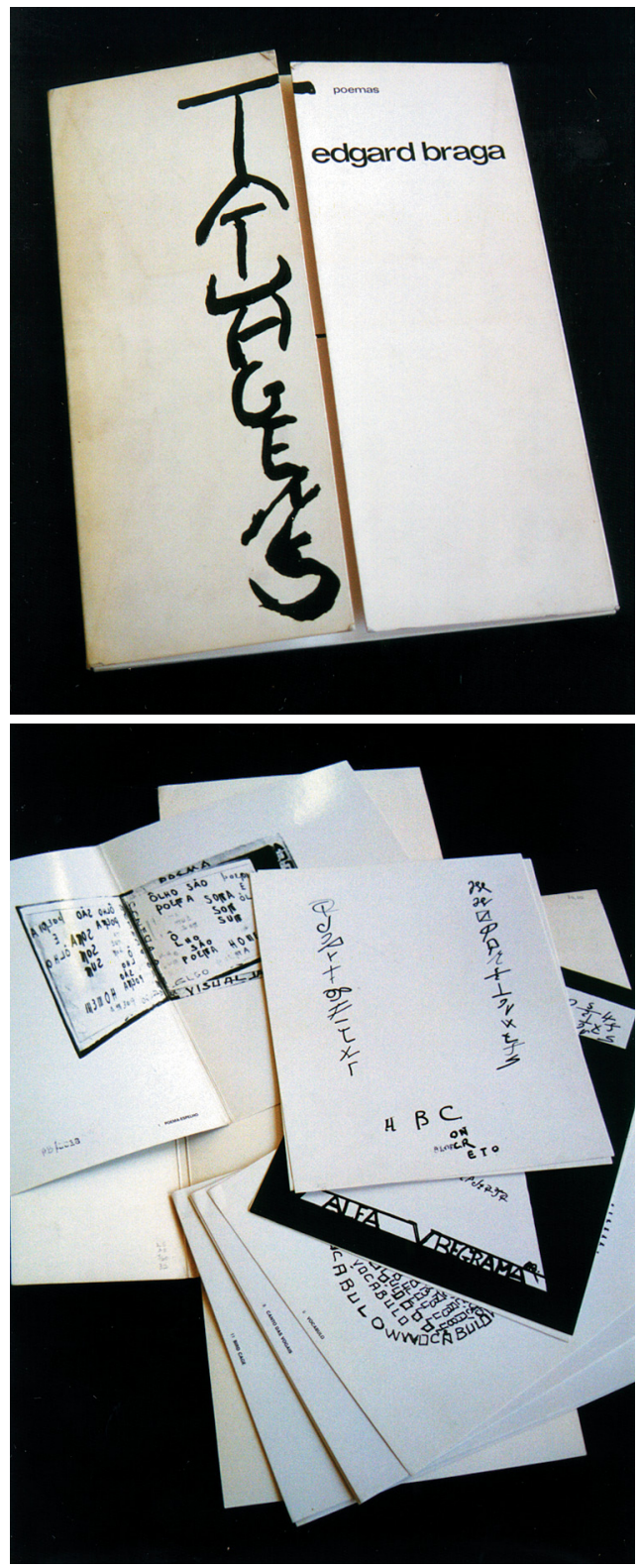

Edgard Braga, Tatuagens, 1976. 

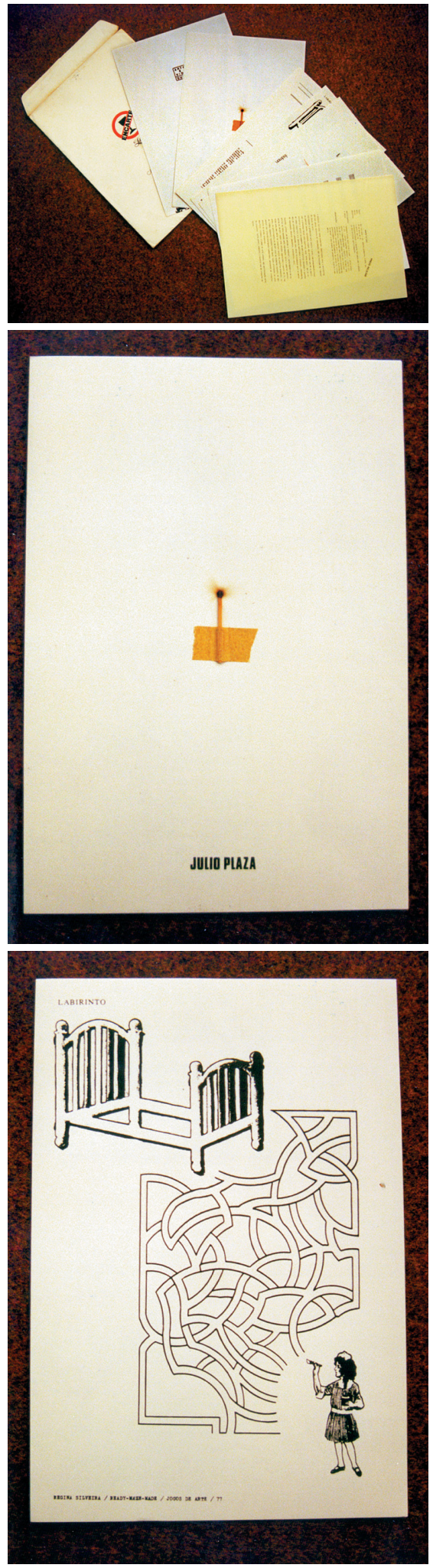

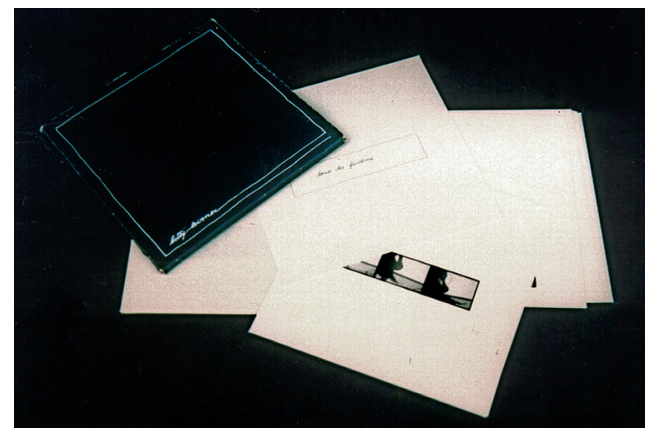

Betty Leirner, Squares of light, 1978.
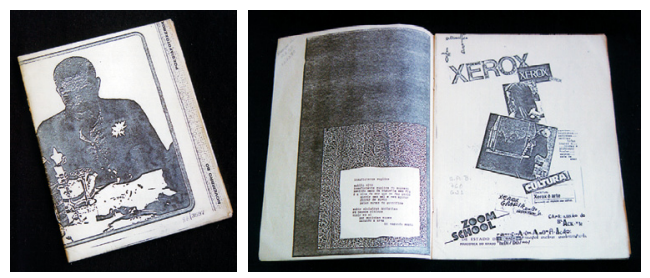

Hudnilson Jr., PoesiaFotoXerox, 1980.
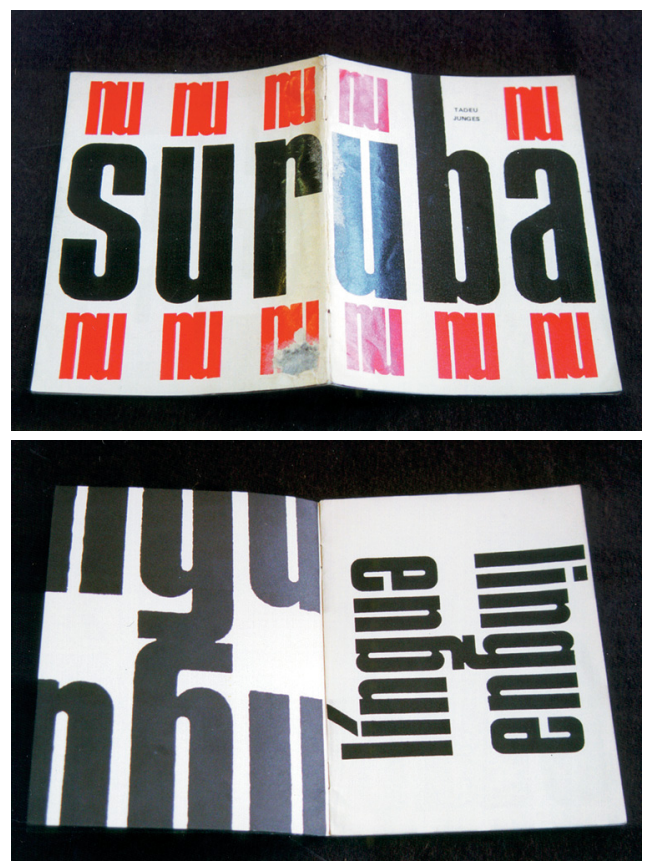

Tadeu Junges, Suruba, 1980.

Encarte Lei Seca, 1979.

Participação de Carlos Fajardo, Gabriel Borba, Julio Plaza (foto do centro), Leonhard Duch, Mauricio Fridman e Regina Silveira (foto de baixo). 


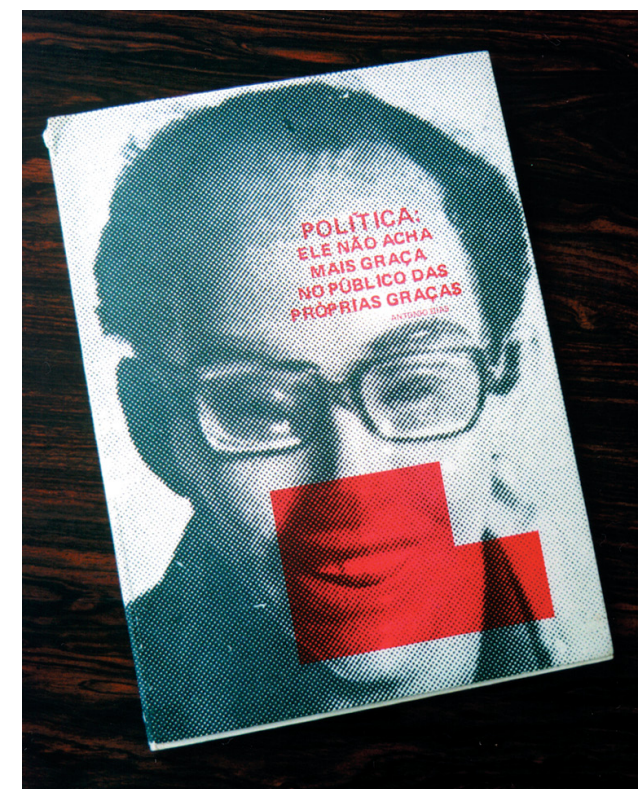

Antonio Dias,

Politica: ele não acha mais graça

no público das próprias graças, s.d.

[1979]
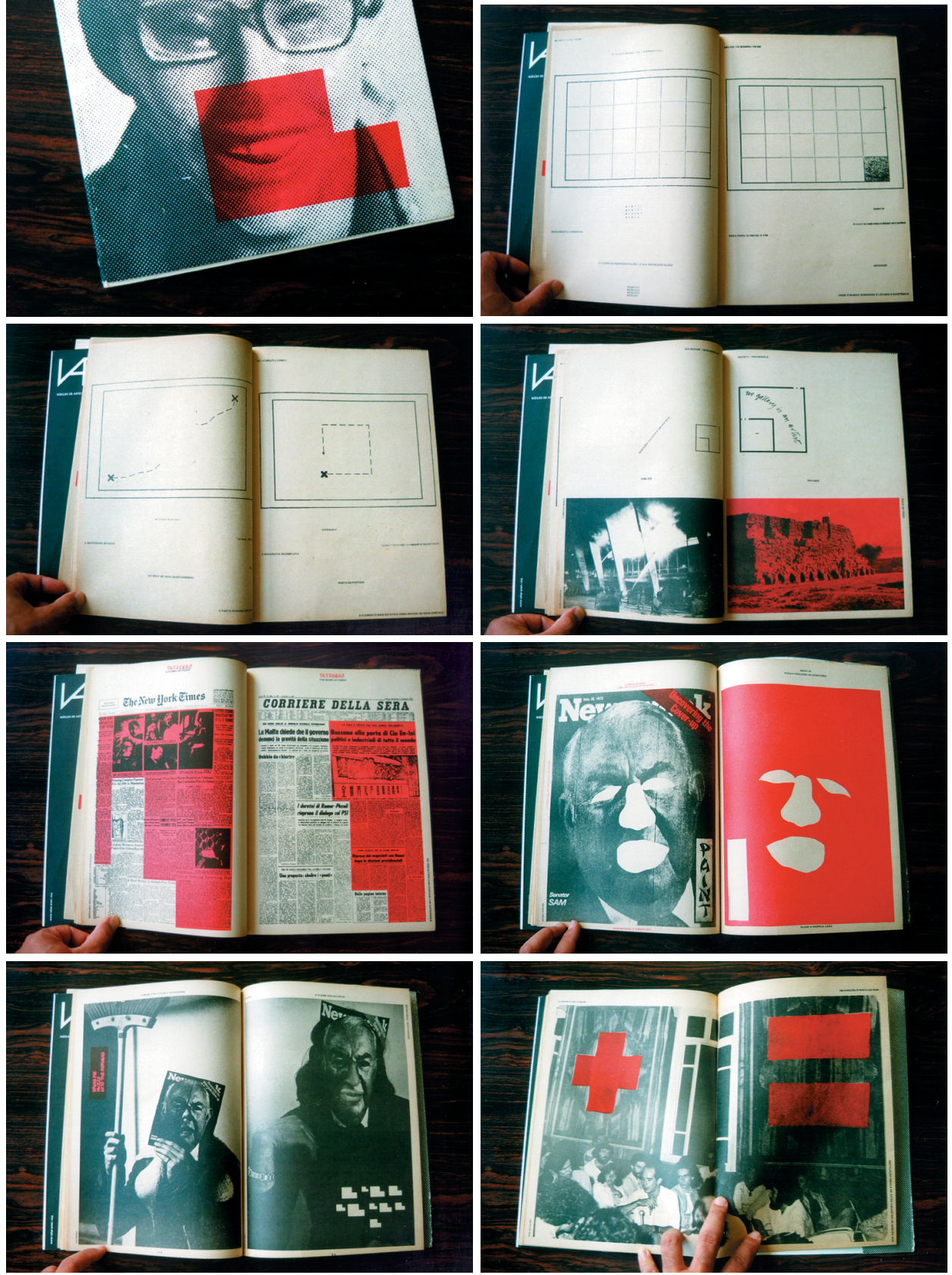

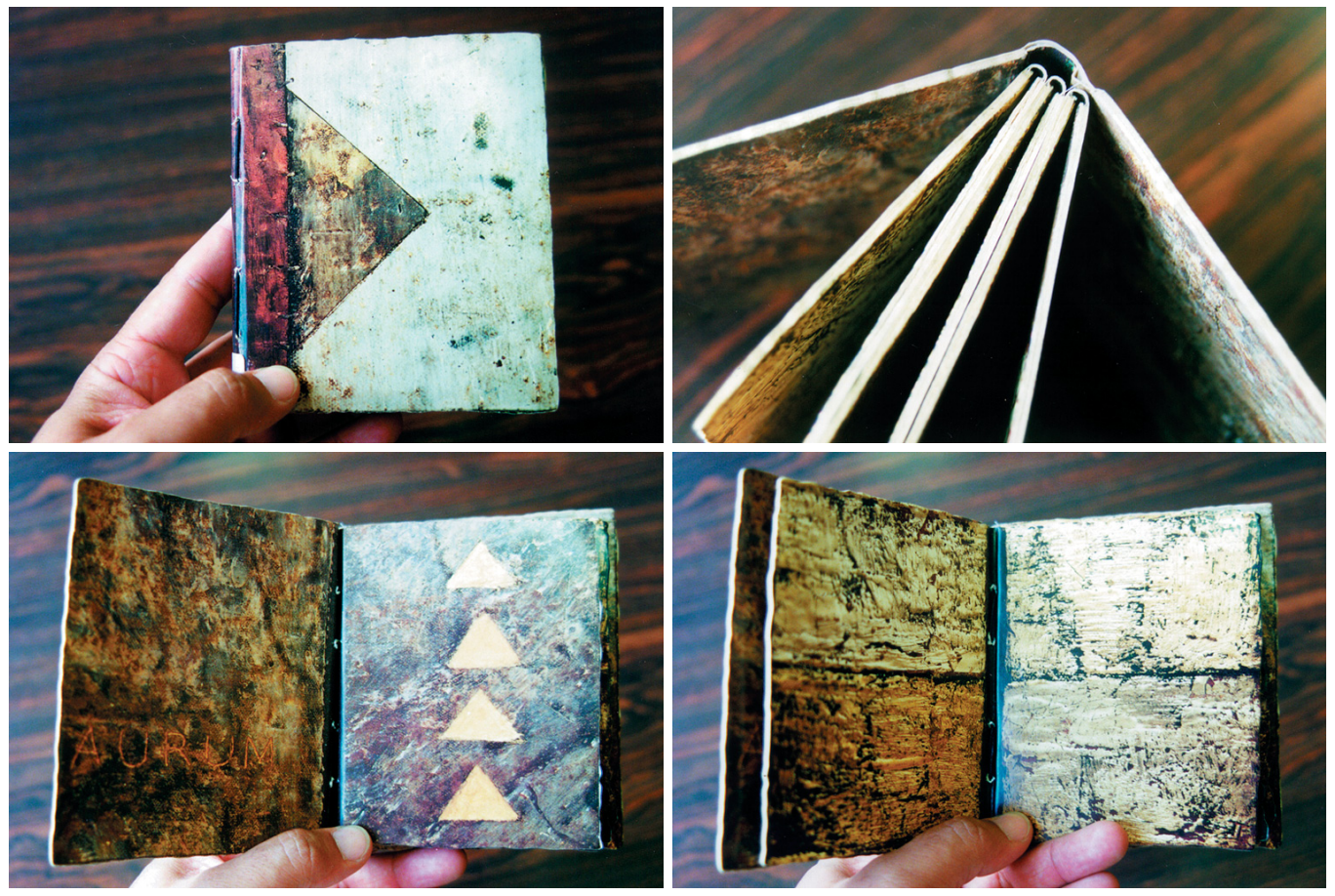

Flávia Ribeiro, Aurum: ícone perfeito; operando entre o secular e o sagrado; pater noster, 1991.

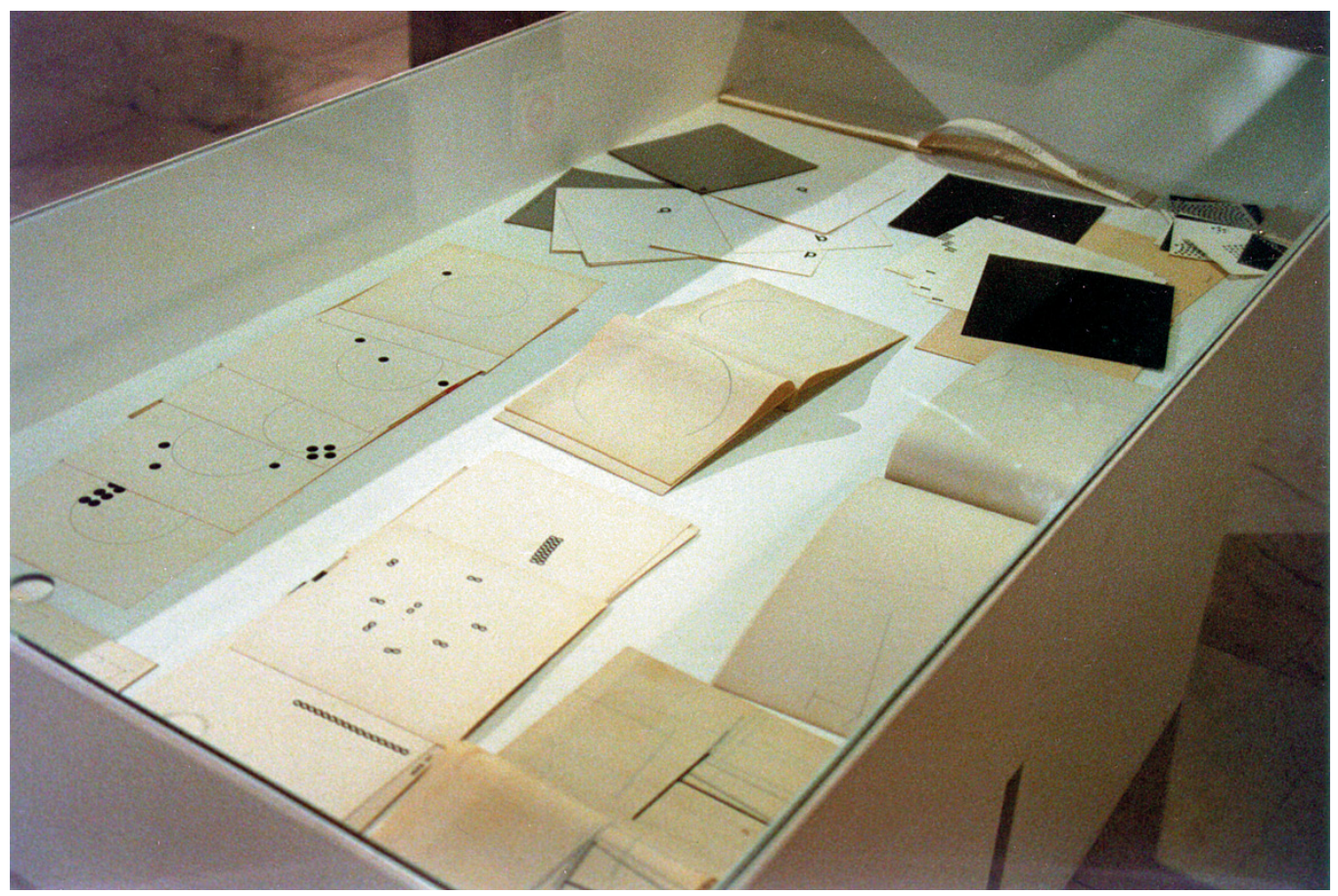

Mira Schendel, vitrina com cadernos na exposição No Vazio do Mundo, São Paulo, 1996-1997. 